Review Article 2019

\title{
Recent Studies on the Singhbhum Craton
}

\author{
DHRUBA MUKHOPADHYAY* and ABDUL MATIN \\ Formerly of Department of Geology, University of Calcutta, India
}

(Received on 01 September 2019; Accepted on 10 September 2019)

\section{Introductory Remarks}

Like other shield areas of the world, the Singhbhum Craton is made up of expansive granitoid terranes that are either flanked by or have internal screens of supracrustal belts in varying metamorphic states. The mafic-dominated supracrustal belts are thought to represent segments of the ancient oceanic crust and their isotopic characters provide information about the Hadean and Eoarchean mantle. Globally, evidence is accumulating about the existence of continental crust even in Hadean times (4.0-4.5 Ga) from the study of zircon grains in Archean sediments and xenocrystic zircon grains in granitic gneisses. In recent years, more refined isotopic studies of $\mathrm{Pb}, \mathrm{Sm}, \mathrm{Nd}, \mathrm{Lu}, \mathrm{Hf}$, and particularly of short lived isotopes and oxygen isotopes have provided new information on the processes of crustal growth during the Hadean times and on the physical and chemical conditions existing on the surface of the early Earth. How much of the Archean felsic continental crust was juvenile and how much of it was due to reworking of older crusts is a matter of debate. There is also a raging controversy on whether the Archean geodynamic process was driven by subduction or by plume driven underplating or intraplating. The Singhbhum craton, with its supracrustal belts and the granitoid terrains of Paleoarchean to Neoarchean age is an ideal terrain to test the different models of Archean crustal growth. This review confines itself principally to the new information that has come during the last five years. The older work had earlier been summarized in Mukhopadhyay (2001) and Sarkar and Gupta (2012).

\section{Singhbhum Craton}

Singhbhum Craton, also designated as the Iron Ore

*Author for Correspondence: E-mail:dhruba-38@yahoo.co.uk
Craton (Saha, 1994), is one of the oldest cratonic blocks in Peninsular India, and encompasses an area of $\sim 39,000 \mathrm{~km}^{2}$ and forms a N-S elongate ovoid block between $84.5^{\circ} \mathrm{E}$ to $86.5^{\circ} \mathrm{E}$ and $21^{\circ} \mathrm{N}$ to $22.75^{\circ} \mathrm{N}$ in eastern India (Fig. 1). Deposition of different supracrustal sequences and emplacement of granitoid rocks built up the craton during the time span of 3.5$2.5 \mathrm{Ga}$. Evidence has recently emerged about the existence of continental crust during the EoarcheanHadean time.

The Singhbhum Craton (SC) (Fig. 1) lies south of the Central Indian Tectonic Zone (CITZ) and is bounded in the north by the arcuate, northerly convex Singhbhum Shear Zone (SSZ) (Fig. 1). Traditionally (Sarkar and Saha, 1962; Saha, 1994), the southern branch of the western boundary of SSZ is thought to veer towards SW, wrapping round the cratonic nucleus. But, later work (Mukhopadhyay et al., 1991; Blackburn and Srivastava, 1994) suggests that the SSZ should pass south of Ongarbira Volcanics and Jojohatu Ultramafics.

The Barakot-Akul Fault Zone (Crowe et al., 2003) and in its continuation the Sukinda Thrust (Fig. 1) demarcate the southern boundary between the $\mathrm{SC}$ and the Rengali Province (RP). The RP, principally made of high-grade Rengali granulite suite of rocks, is thrusted over the SC (Bose et al., 2015). The RP separates the SC from the main Eastern Ghats Granulite Belt (EGGB). Ghosh et al. (2016a) suggested that the RP shows imprints of a major 500 Ma transpressive deformation resulting from oblique collisional accretion of the Eastern Ghats belt to the Singhbhum Craton. They correlated this deformation with the Pan-African orogeny. Bose et al. (2015) and Mahapatro et al. (2012) have interpreted the granulite 


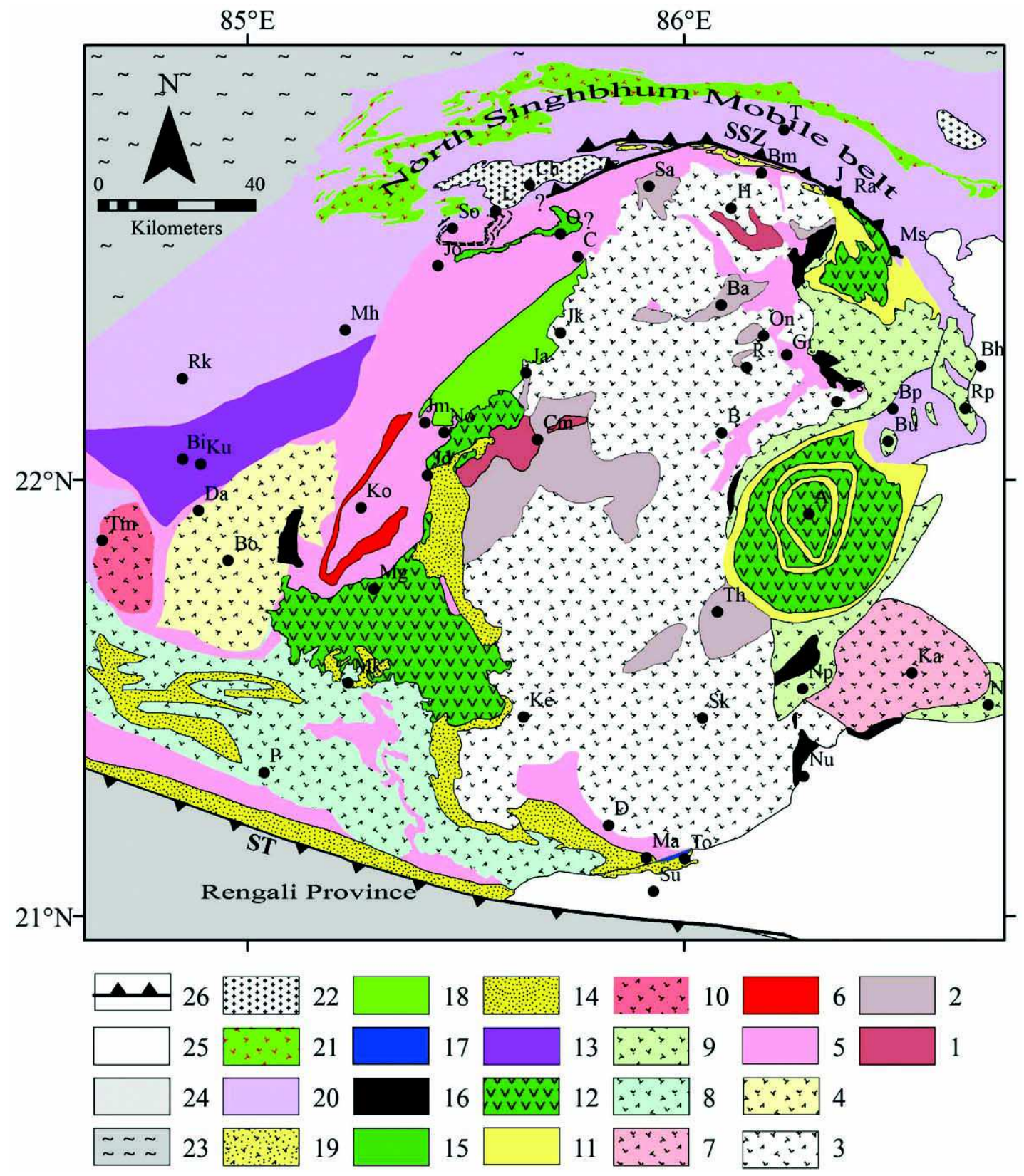

Fig. 1: Simplified geological map of the Singhbhum craton (after Saha, 1994 and modified from other sources mentioned in the text). 1 - OMG, 2 - OMTG, 3 - Singhbhum Granite, 4 - Bonai Granite, 5 - Iron Ore Group, Malayagiri Supracrustals, 6 - BIF in western IOG, 7 - Kaptipada Granite, 8 - Pallahara Gneiss, 9 - Mayurbhanj Granite, 10 - Tamperkola Granite, 11 - Dhanjori Siliciclastics, 12 - Dhanjori-Simlipal-Jgannathpur-Malangtoli Volcanics, 13 - Darjing Group, 14 - MahagiriKeonjhar-Mankaharchua-Deograh Siliciclastics, 15 - Ongarbira Volcanics, 16 - Gabbro- anorthosite-ultramafics, 17 Sukinda Ultramafics, 18 - Kolhan Group, 19 - Soda Granite, Arkasani Granite, Kuilapal Granite, Beldih Granite. 20 Singhbhum Group, 21 - Dalma Volcanics, 22 - Chakradharpur Granite, 23 - Chhotanagpur Granite Gneiss, 24 - Rengali Province, 25 - Gondwanas, Younger Sediments and Alluvium 26 - hear Zone/Fault. A - Amjhor, B - Badampahar, Ba Bahalda, Bh - Baharagora, Bi - Birtola, Bm - Bisrampur, Bn - Brahmani, Bo - Bonai, Bp - Bangriposi, Br - Bhaunra, Bs - Besoi, Bu - Bhuasuni, C - Chaibasa, Ch - Chakradharpur, Cm - Chmpua, D - Daitari, Da - Darjing, Gr - Gorumahisani, H - Haludpukur, J - jaduguda, Ja - Jagannathpur, Jd - Joda, Jk - Jorapokhar, Jm - Jamda, Jo - Jojuhatu, Ka - Kaptipada, Ke - Keonjhar, Ko - Koira, Ku - Kumakela, L - Lotapahar, Ma - Mahagiri, Mg - Malangtoli, Mh - Manoharpur, Mk Mankaharchua, Ms - Mosabani, N - Nilgiri, No - Noamundi, Np - Notopahar, Nu - Nuashahi, O - Ongarbira, On Onlajori, P - Pallahara, R - Rairangpur, Ra - Rakha, Rk - Raurkela, Rp - Romapahari, Sa - Seraikela, Sk - Satkosia, So - Sonua, Su - Sukinda, T - Tatanagar, Th - Thakurmunda, Tm - Tamperkola, To - Tomka. The Singhbhum Group, the Dalma Volcanics and other associated rocks constitute the North Singhbhum Mobile Belt 
facies lenses within the gneisses of the RP to represent thrusted slices of the deeper crust of the Singhbhum Craton. The RP is interpreted by Bhattacharya et al. (2016) as an accretion zone, formed when the EGGB was welded to the Greater India landmass during the Grenvillian or Pan-African time.

The eastern boundary of the Singhbhum Craton is marked by the N-S to NNE-SSW trending, sinistral transcontinental deformation zone, named as the Eastern Indian Tectonic Zone (EITZ), developed during 876-784 Ma; EITZ continues northward cutting across the SSZ and the North Singhbhum Mobile Belt (Chatterjee et al., 2010).

Four principal units make up the craton: (1) Older Metamorphic Group (OMG) and Older Metamorphic Tonalite Gneiss (OMTG), (2) large granitic massifs of Singhbhum Granite (SBG), Bonai Granite (BG), Kaptipada (Nilgiri) Granite (KG), Mayurbhanj Granite tonalite gneisses within the SBG. The bulk of what is shown as OMTG in the map of Saha (1994) (Fig. 1) belongs, according to them, to the TTG suite of Phase I of the Singhbhum Granite. This point is to be settled by careful field mapping coupled with more petrographical, geochemical and geochronological data. The OMTG rocks are gneissic in nature, typically tonalite-trondhjemite-granodiorite (TTG) in composition (Fig. 2A), and are comparable to the Archean TTG rocks of the world. Field relations in outcrops indicate intrusion of successive phases of tonalite to granite magma. Quartzo-feldspathic products of partial melting are present in boudin necks and in small scale shear zones (Hofmann and Mazumder, 2015). Upadhyay et al. (2014) and Pandey et al. (2019) have included some rocks compositionally falling in the granite field within the OMTG. However, as described by them, the TTG and the granites have different zircon dates (see
(MBG) and Pallahara Gneiss (PLG), (3) supracrustal rocks of several Iron Ore Basins, and (4) belts of younger supracrustal rocks. In addition to these, there are the Malangtoli Volcanics, the Jagannathpur Volcanics and the Ongarbira Volcanics, the dyke swarms of Newer Dolerite, and intrusive bodies of ultramaficsgabbro-anorthosite suite. Insufficient geochronological data and rarity of contact relations in outcrops have hampered the understanding of temporal relation between these groups.

\section{Granitoids in the Singhbhum Craton}

\section{Older Metamorphic Tonalite Gneiss (OMTG)}

The OMTG rocks occupy a total area of about $900 \mathrm{~km}^{2}$ east and south of Champua; smaller outcrops are scattered throughout the Singhbhum Granite body (Fig. 1). Prabhakar and Bhattacharya (2013) restrict the term OMTG only to the smaller enclaves of migmatitic
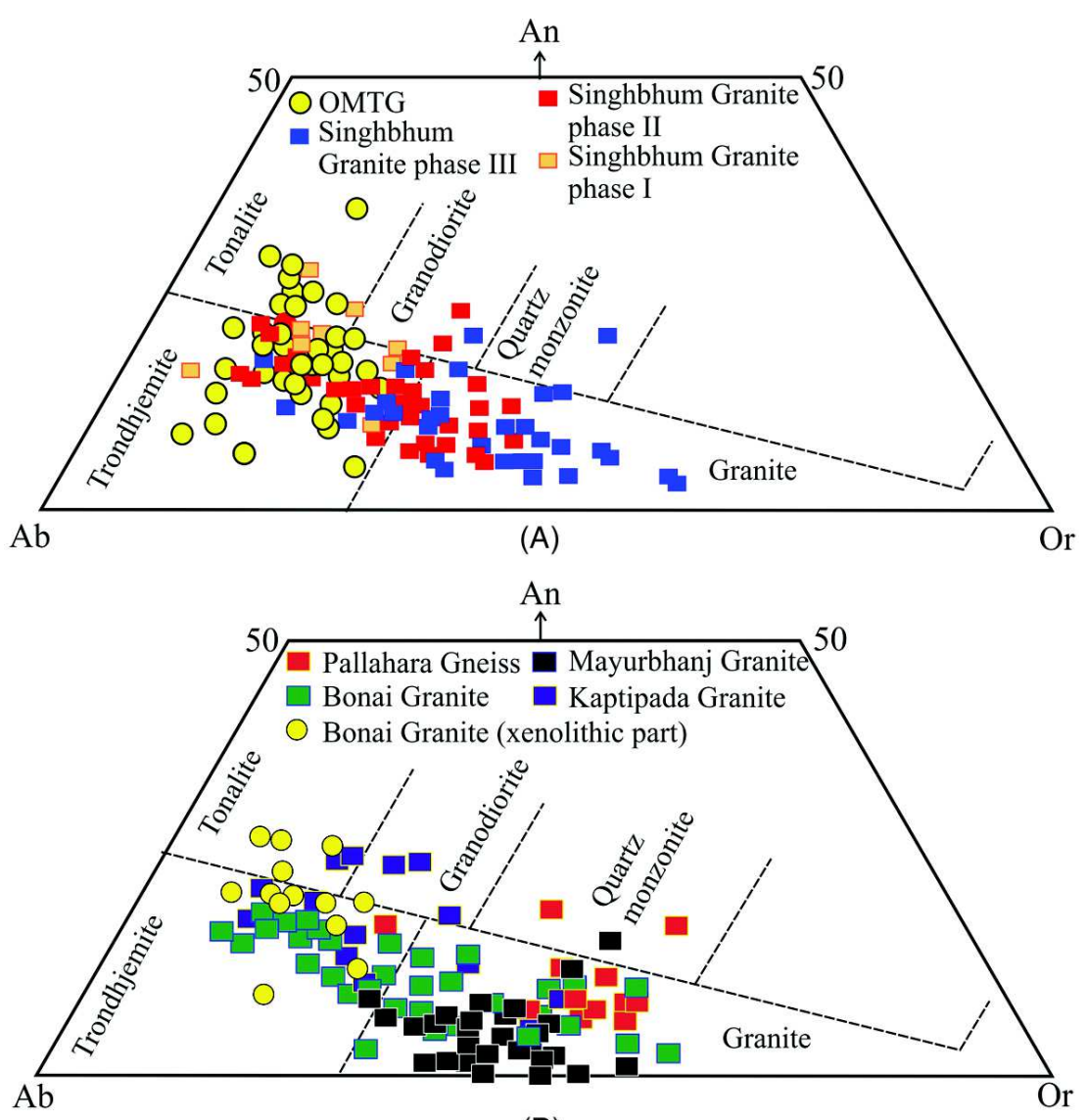

(B)

Fig. 2: A and B. Normative Ab-An-Or plots of granitoid rocks in the Singhbhum craton. Data source: Saha et al. (1984), Sengupta et al. (1991), Saha (1994), Tait et al. (2011), Nelson et al. (2014), Upadhyay et al. (2014), Dey et al. (2017), Pandey et al. (2019) 
below), different REE patterns and different geochemical characteristics. No field relations between the two are described. We are of the opinion that the granite samples should not be grouped with the TTG of the OMTG.

Nelson et al. (2014) described gently sloping REE patterns with weak negative Eu anomaly and low HREE abundances for OMTG (Fig. 3A); this is consistent with a model of derivation by fluid absent partial melting of a lower crustal source with retained restitic feldspar following melt extraction. A tonalite enclave within the Singhbhum Granite near Keonjhar also shows a sloping LREE but flat HREE patterns and -ve Eu anomaly (Fig. 3A) (Dey et al., 2017). A petrogenetic model of dehydration melting of a mafic source in absence of garnet with plagioclase as residual or fractionating phase has been suggested. The minimum temperature of the tonalite magma corresponding to the enclave has been estimated from zircon saturation temperature to be $\sim 750^{\circ} \mathrm{C}$, and the pressure at emplacement depth is determined from $\mathrm{Al}$ in hornblende to be $3.5+0.1 \mathrm{~kb}(\sim 12 \mathrm{~km}$ depth $)$ (Dey et al., 2017). Pandey et al. (2019) reported that the OMTG trondhjemites have enriched LREE, no Eu anomaly and gently sloping to flat HREE, while the OMTG granite has strong Eu anomaly and flat HREE pattern (Fig. 3A). For the tonalitic-trondhjemitic rocks a petrogenetic model of dehydration melting in absence of garnet with plagioclase as residual or fractionating phase has been suggested. As already mentioned, it is debatable whether the granite samples should be included within the OMTG.

The radiometric dates obtained from OMTG samples by different workers cover a wide range (Table 1, Fig. 4). Geochronological data suggest that the TTG suite in OMTG was emplaced in different pulses at 3.52, 3.47-3.43 and $\sim 3.40-3.33 \mathrm{Ga}$; xenocrysts of 3.47-3.41 Ga zircon from the older pulse are present in the younger TTGs. The granitic components are distinctly younger at 3.31-3.28 Ga. The major metamorphic pulses were at $~ 3.3-3.2,3.14$ 3.11, 2.96-2.95 and 2.45 Ga. The ages of inherited zircons (xenocrystic cores) from older rocks range from $\sim 4.2$ to $3.6 \mathrm{Ga}$. It is interesting to note that the $3380+11$ Ma old granitoids on the Deo Nala display rafts of BIF and are clearly intrusive into the latter. The mean CHIME date of monazite in OMTG tonalite gneiss is $3306+22 \mathrm{Ma}$ (Prabhakar and Bhattacharya,
2013). This probably represents a metamorphic growth event.

Chaudhuri et al. (2018) reported that the Eoarchean $(\sim 3.7 \mathrm{Ga})$ cores of zircons in the OMTG and the Paleoarchean $(\sim 3.6$ to $\sim 3.3)$ zircon grains in the OMTG have negative $\varepsilon_{\mathrm{Hf}(\mathrm{t})}$ values of $-4.7+1.4$ to $-6.6+1.1$ and $-0.4+1.2$ to $-3.7+1.8$ respectively (Fig. $5)$. They interpret that the Hadean enriched reservoir persisted at least till Paleoarchean from which the felsic melts were derived, but these were variably mixed with depleted mantle-derived juvenile magma during Eoarchean to Paleoarchean. On the contrary, Dey et al. (2017) reported suprachondritic Hf isotopic signatures with positive values of $\varepsilon_{\mathrm{Hf}(\mathrm{t})}$ ranging from +2.9 to +2.2 and concluded that the $3.47 \mathrm{Ga}$ old tonalite was generated by shallow melting of a juvenile mafic crust. Pandey et al. (2019) reported weak subchondritic to suprachondritic $\varepsilon_{\mathrm{Hf}(\mathrm{t})}$ values of -1.2 to +4.5 for the Paleoarchean OMTG zircon grains (Fig. 5). This implies the existence of a separate depleted reservoir during Paleoarchean which was probably complementary to the ancient enriched reservoir inferred by Chaudhuri et al. (2018). Therefore, different sources contributed to different pulses of the OMTG.

\section{Singhbhum Granite}

The large oval-shaped body of the Singhbhum Granite constitutes more than one-third of the Singhbhum craton (Fig. 1). It is a suite of granitoid rocks ranging in composition from tonalite to granite and these were emplaced in different pulses. Professor A. K. Saha and his co-workers demarcated the complex granite body into 12 separate units on the basis of mutual intrusive relations and distinctive primary foliation pattern of different units (Saha and Ray, 1984; Saha, 1994). On the basis of field relations, petrography and geochemistry, the 12 domal magmatic bodies were grouped into three closely related phases which were emplaced successively. The earliest phase (Phase I) is relatively K-poor, granodiorite-trondhjemite in composition, while the later phases (Phase II and III) are granodiorite that grade to monzogranite and granite (Saha, 1994) (Fig. 2A). Phase III covers the largest area of the Singhbhum Granitic complex. Later work has brought into light greater range in composition of the different units of the SBG (Fig. 2A). The OMTG rocks are exclusively TTGs (tonalite-trondhjemite- 
Table 1: Selective geochronological data from the Singhbhum Craton

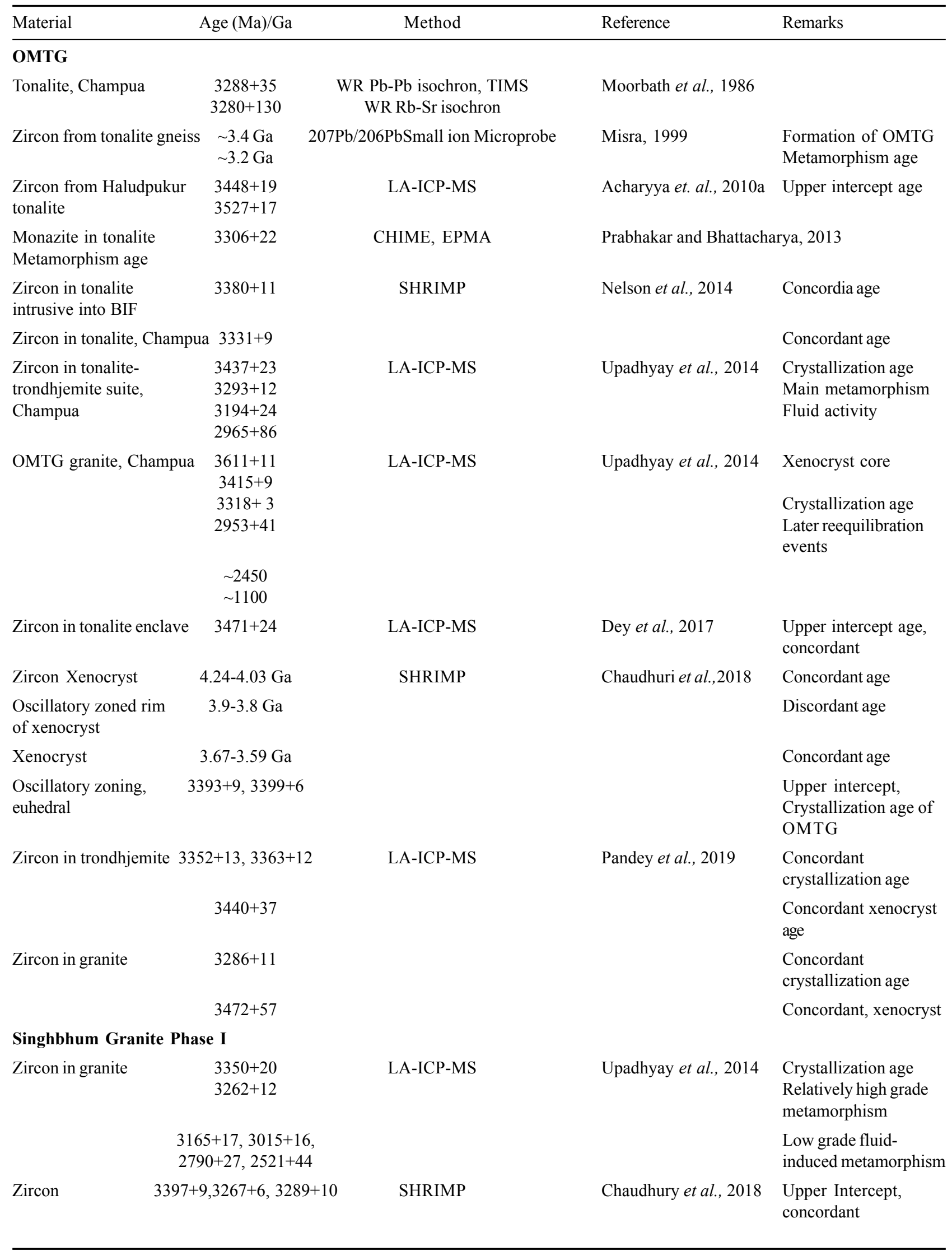




\begin{tabular}{|c|c|c|c|c|}
\hline \multicolumn{5}{|c|}{ Singhbhum Granite Phase II } \\
\hline Granitoid rocks & $3292+51$ & WR $\mathrm{Pb}-\mathrm{Pb}$ isochron, TIMS & \multicolumn{2}{|c|}{ Moorbath and Taylor, 1988} \\
\hline $\begin{array}{l}\text { Zircon from Keonjhar- } \\
\text { Bhaunra pluton }\end{array}$ & $3280+7$ & $\begin{array}{c}207 \mathrm{~Pb} / 206 \mathrm{~Pb} \\
\text { Small ion Microprobe }\end{array}$ & \multicolumn{2}{|l|}{ Misra, 1999} \\
\hline $\begin{array}{l}\text { Zircon from Keonjhar- } \\
\text { Bhaunra pluton }\end{array}$ & $\begin{array}{l}3291+9 \\
3496+5\end{array}$ & SHRIMP & Tait et al., 2011 & $\begin{array}{l}\text { Concordant age } \\
\text { Inherited zircon } \\
\text { (subhedral) age }\end{array}$ \\
\hline Zircon in monzogranite & $3326+5$ & SHRIMP & Nelson et al., 2014 & $\begin{array}{l}\text { Near Rairangpur, } \\
\text { Concordant age }\end{array}$ \\
\hline \multicolumn{2}{|c|}{ Zircon in granite and trondhjemite } & $3336+4$ & LA-ICP-MS & $\begin{array}{l}\text { Upadhyay et al., } 2014 \\
\text { Crystallization age }\end{array}$ \\
\hline & $\begin{array}{l}3463+8 \\
3281+4 \\
3163+9\end{array}$ & & & $\begin{array}{l}\text { Xenocrystic core } \\
\text { Metamorphism } \\
\text { Low grade } \\
\text { metamorphism }\end{array}$ \\
\hline $\begin{array}{l}\text { Zircon in porphyritic } \\
\text { granite of Keonjhar- } \\
\text { Bhaunra pluton }\end{array}$ & $3308+31$ & LA-MC-ICPMS & Dey et al., 2017 & \\
\hline Zircon in trondhjemite & $3334+15$ & LA-ICP-MS & Pandey et al., 2019 & $\begin{array}{l}\text { Concordant, } \\
\text { Crystallization ages }\end{array}$ \\
\hline Zircon in granite & $3330+9$ & & & \\
\hline \multicolumn{5}{|c|}{ Singhbhum Granite Phase III } \\
\hline Zircon in granodiorite & $\begin{array}{l}3332+5 \\
3368+7\end{array}$ & SHRIMP & Nelson et al., 2014 & $\begin{array}{l}\text { West of Gorumahishani } \\
\text { Xenocryst from same } \\
\text { sample }\end{array}$ \\
\hline Zircon in granodiorite & $3299+7$ & & & East of Keonjhar \\
\hline $\begin{array}{l}\text { Zircon in pegmatitic } \\
\text { granodiorite }\end{array}$ & $3285+7$ & & & $\begin{array}{l}\text { North of Seraikela, } \\
\text { Concordant age }\end{array}$ \\
\hline Zircon in granite & $\begin{array}{l}3445+4 \\
3347+8\end{array}$ & LA-ICP-MS & Upadhyay et al., 2014 & $\begin{array}{l}\text { Crystallization age } \\
\text { Metamorphism }\end{array}$ \\
\hline \multicolumn{3}{|c|}{$3128+42,2962 \pm 33$} & & $\begin{array}{l}\text { Fluid mediated } \\
\text { alteration }\end{array}$ \\
\hline \multirow[t]{2}{*}{$\begin{array}{l}\text { Zircon in nonporphyritic } \\
\text { granite }\end{array}$} & $3308+31$ & LA-MC-ICPMS & Dey et al., 2017 & $\begin{array}{l}\text { Upper intercept } \\
\text { Crystallization age }\end{array}$ \\
\hline & $3304+25$ & & & Sub-concordant zircon \\
\hline Older Core & $77+11,3367+7$ & SHRIMP & Chaudhuri et al., 2018 & Concordant age \\
\hline Euhedral & $3286+6$ & & & Upper intercept \\
\hline \multirow[t]{2}{*}{ Zircon in trondhjemite } & $3470+10$ & LA-ICP-MS & Pandey et al., 2019 & $\begin{array}{l}\text { Concordia age, } \\
\text { Crystallization ages }\end{array}$ \\
\hline & $3292+19$ & & & \\
\hline Zircon in granite & $3351+8$ & & & \\
\hline Zircon in granodiorite & $3300+7$ & SHRIMP & Olierook et al., 2019 & \\
\hline \multicolumn{5}{|l|}{ Bonai Granite } \\
\hline Zircon in tonalite xenolith & $3380+64$ & U-Pb, TIMS & Sengupta et al., 1996 & $\begin{array}{l}\text { Discordant, Upper } \\
\text { intercept age }\end{array}$ \\
\hline Xenocryst & 3448 & & & $\begin{array}{l}\text { Discordant, Upper } \\
\text { intercept }\end{array}$ \\
\hline Tonalite xenolith & $3369+57$ & $\mathrm{WR} \mathrm{Pb}-\mathrm{Pb}$ isochron & & \\
\hline Host granitoid & $3163+126$ & & & Errorchron \\
\hline
\end{tabular}




\begin{tabular}{|c|c|c|c|c|}
\hline \multirow[t]{2}{*}{ Zircon in granite } & $3370+10$ & \multirow[t]{2}{*}{ LA-ICP-MS } & \multirow[t]{2}{*}{ Chakraborty et al., 2019} & Emplacement age \\
\hline & $\begin{array}{c}033+38,2809+29, \\
2531+22\end{array}$ & & & $\begin{array}{l}\text { Metamorphic/ } \\
\text { hydrothermal ages }\end{array}$ \\
\hline \multicolumn{5}{|l|}{ Tamperkola Granite } \\
\hline Zircon in granite & $\begin{array}{c}2809+12 \\
3391+8,3251+8\end{array}$ & $\begin{array}{c}207 \mathrm{~Pb} / 206 \mathrm{PbSmall} \text { ion } \\
\text { Microprobe }\end{array}$ & $\begin{array}{l}\text { Bandyopadhyay } \\
\text { et al., } 2001\end{array}$ & $\begin{array}{l}\text { Crystallization age } \\
\text { Xenocrystic cores }\end{array}$ \\
\hline Zircon in acid volcanics & $2822+67$ & & & $\begin{array}{l}\text { Volcanics related to } \\
\text { granite }\end{array}$ \\
\hline \multicolumn{5}{|l|}{ Mayurbhanj Grnite } \\
\hline Zircon in granophyre & $\sim 2.8 \mathrm{Ga}$ & LA-ICP-MS & Acharyya et al., 2010a & $\begin{array}{l}\text { Discordant grains, upper } \\
\text { intercept of discordia } \\
\text { curve }\end{array}$ \\
\hline Zircon in aplogranite & $3080+8,3092+5$ & $\begin{array}{c}207 \mathrm{~Pb} / 206 \mathrm{PbSmall} \text { ion } \\
\text { Microprobe }\end{array}$ & Misra et al., 1999 & \\
\hline Zircon in gneissic granite & $3089+6$ & La-ICP-Ms & Chakraborti et al., 2019 & Concordant age \\
\hline \multicolumn{5}{|l|}{ Pallahara Gneiss } \\
\hline \multirow[t]{2}{*}{ Zircon in granite gneiss } & $2776+7$ & LA-SF-ICP-MS & $\begin{array}{l}\text { Chattopadhyay et al., } \\
2015\end{array}$ & $\begin{array}{l}\text { Concordant } \\
\text { age, mantle \& core }\end{array}$ \\
\hline & $2721+10$ & & & Only mantle \\
\hline \multirow[t]{2}{*}{ Zircon in gneiss } & $2792+75$ & LA-ICP-MS & Topno et al., 2018 & Upper intercept age \\
\hline & $2788+59$ & & & $\begin{array}{l}\text { Weighted average of } \\
\text { most concordant } 207 \mathrm{~Pb} / \\
206 \mathrm{~Pb} \text { ages }\end{array}$ \\
\hline \multicolumn{5}{|l|}{ OMG } \\
\hline Amphibole in amphibolite & $\begin{array}{l}3314 \pm 4 \\
3286 \pm 6\end{array}$ & ${ }^{40} \mathrm{Ar} /{ }^{39} \mathrm{Ar}$ & Bakshi et al., 1987 & $\begin{array}{l}\text { Cooling age through } \\
500^{\circ} \mathrm{C}\end{array}$ \\
\hline Amphibolite & $3305+60$ & WR Sm-Nd isochron & Sharma et al., 1994 & Formation age \\
\hline Amhibolite \& Tonalite & $3288+35$ & & & $\begin{array}{l}\text { Combined OMG- } \\
\text { OMTG isochron }\end{array}$ \\
\hline $\begin{array}{l}\text { Detrital zircon in quartzite } \\
\text { and quartz-mica schist }\end{array}$ & $\begin{array}{c}3551+13 \\
3583+25 \\
3504+30 \\
3628+38 \\
3.43-3.38 \mathrm{Ga}\end{array}$ & $\begin{array}{c}207 \mathrm{~Pb} / 206 \mathrm{PbSmall} \text { ion } \\
\text { microprobe }\end{array}$ & Goswami et al., 1995 & $\begin{array}{l}\text { Mean core age } \\
\text { Detrital grain } \\
\text { Detrital grain } \\
\text { Detrital grain } \\
\text { Detrital grains }\end{array}$ \\
\hline Zircon overgrowth & $\sim 3.2 \mathrm{Ga}$ & & & Metamorphism age \\
\hline Detrital zircon & $\begin{array}{c}3504+30 \\
3628+38 \\
3.43-3.38 \mathrm{Ga}\end{array}$ & $\begin{array}{l}{ }^{207} \mathrm{~Pb} /{ }^{206} \mathrm{PbSmall} \text { ion } \\
\text { microprobe }\end{array}$ & Misra, 1999 & $\begin{array}{l}\text { Round detrital } \\
\text { Round detrital } \\
\text { ? Metamorphic }\end{array}$ \\
\hline Zircon in schist & $3352+26$ & TIMS & Basu et al., 1996 & $\mathrm{~Pb}$-loss event \\
\hline Euhedral zircon & $3.35 \mathrm{Ga}$ & SHRIMP & Saha et al., 2012 & $\begin{array}{l}\text { Detrital/? Metamorphic } \\
\text { grain }\end{array}$ \\
\hline Monazite in mica schist & $\begin{array}{l}3377+45 \\
3256+46\end{array}$ & CHIME, EPMA & $\begin{array}{l}\text { Prabhakar and } \\
\text { Bhattacharya, } 2013\end{array}$ & Metamorphism ages \\
\hline Zircon in quartzite & $3375+3$ & SHRIMP & Nelson et al., 2014 & $\begin{array}{l}\text { Concordant age Detrital } \\
\text { grain }\end{array}$ \\
\hline Rutile in mica schist & $3317+8$ & LA-ICP-MS & Upadhyay et al., 2014 & $\begin{array}{l}\text { Concordia age of } \\
\text { metamorphism }\end{array}$ \\
\hline Iron Ore Group & $3583+25$ & & & \\
\hline Zircon in basal tuff & $3392+29$ & LA-ICP-MS & Basu et al., 2008 & $\begin{array}{l}\text { Concordant age, } \\
\text { Western BIF }\end{array}$ \\
\hline
\end{tabular}




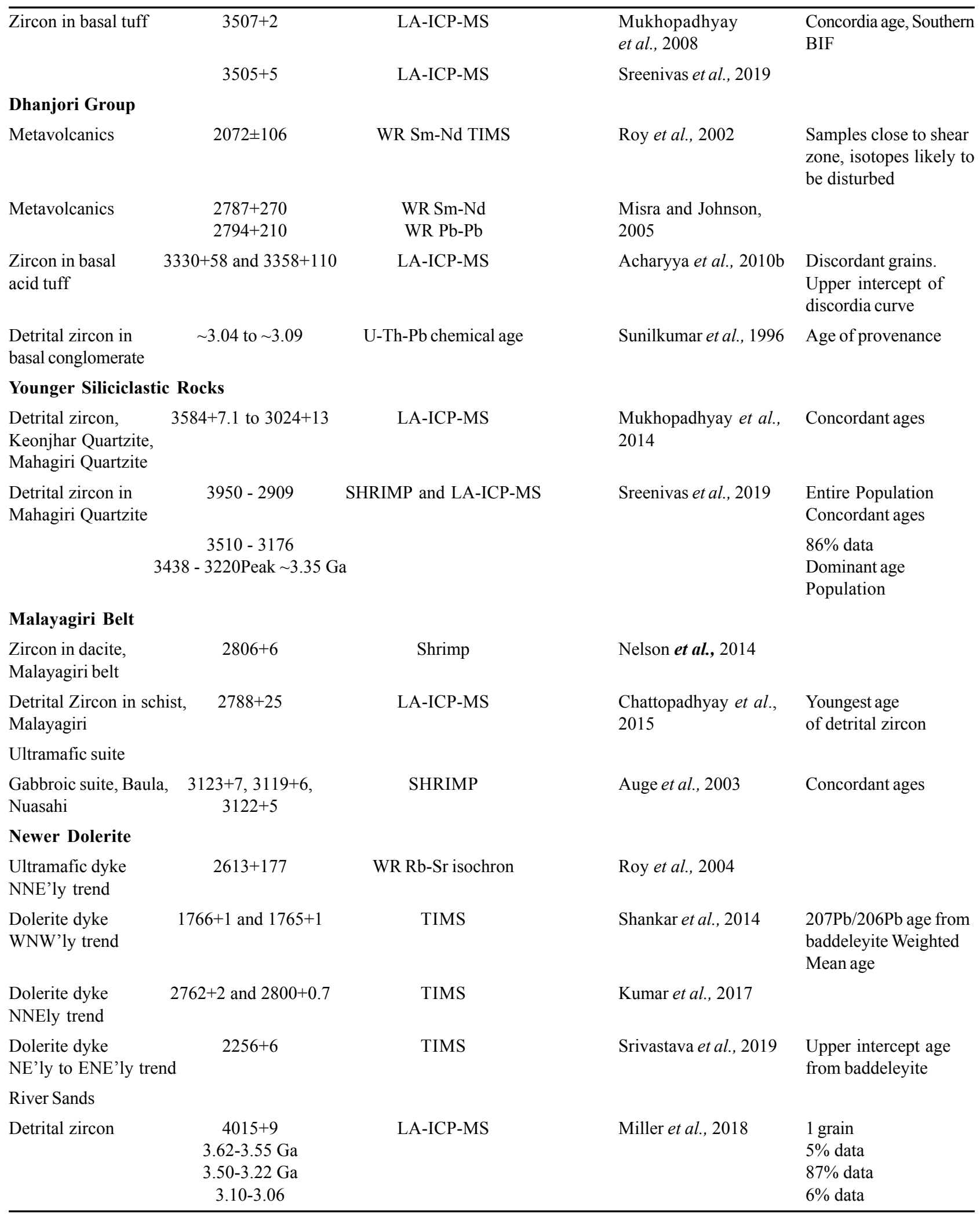

granodiorite), whereas the SBG rocks are granite, monzogranite, granodiorite and trondhjemite (Fig. 2A).

Prabhakar and Bhattacharya (2013) contested the view of Saha and his co-workers and opined that no magmatic fabric is observable in the Singhbhum granitoids. However, they have described the presence 


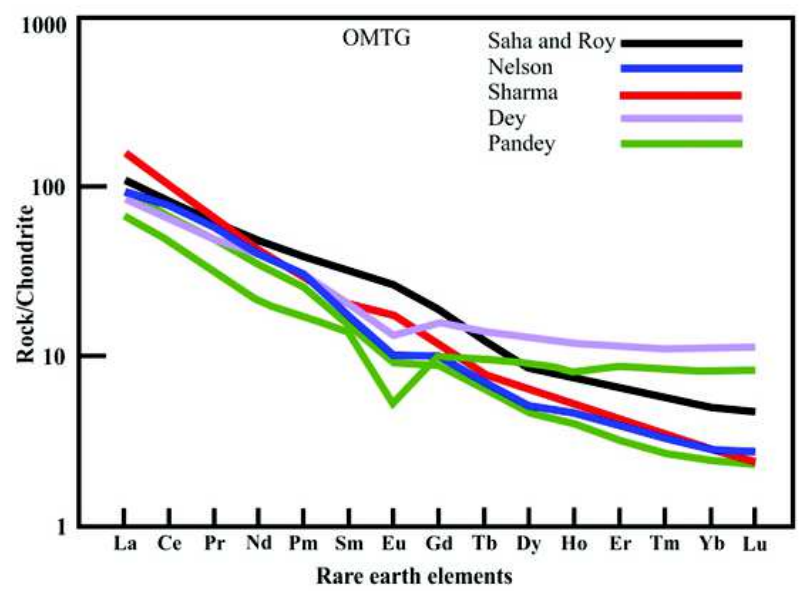

(A)

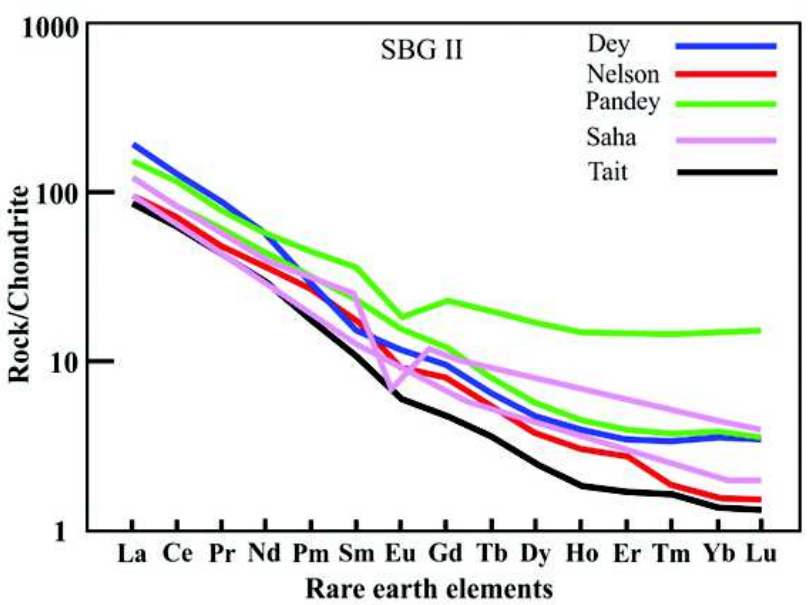

(C)

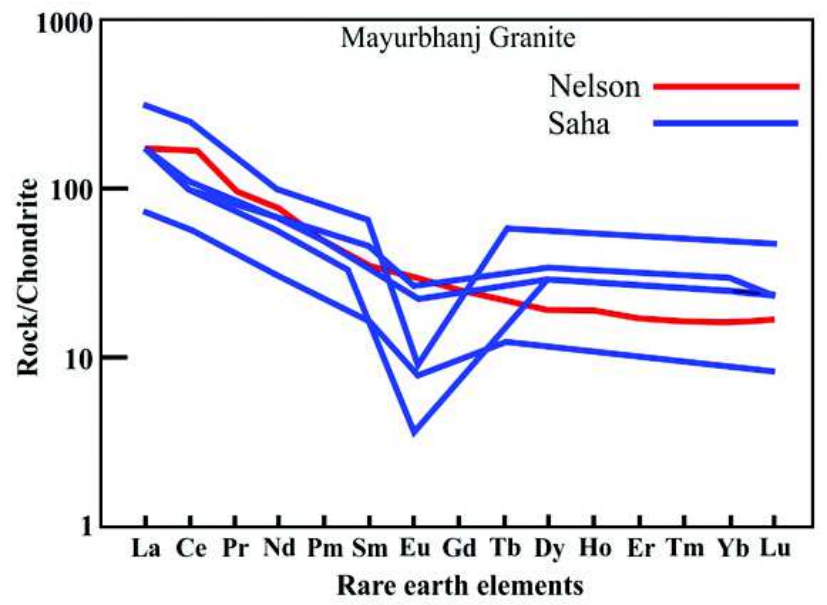

$(\mathrm{E})$

of magmatic flow texture defined by imbricate euhedral plagioclase grains. They recognize a single set tectonic foliation in the SBG granitoids and different

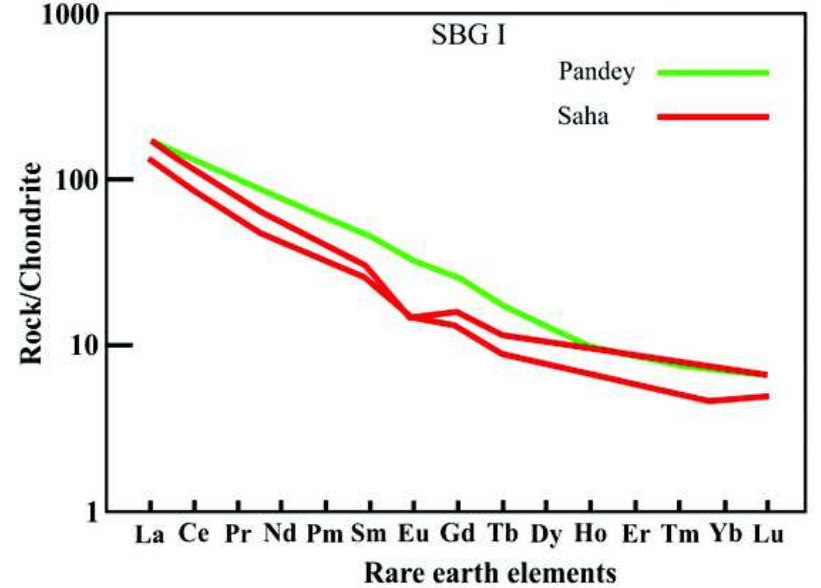

(B)

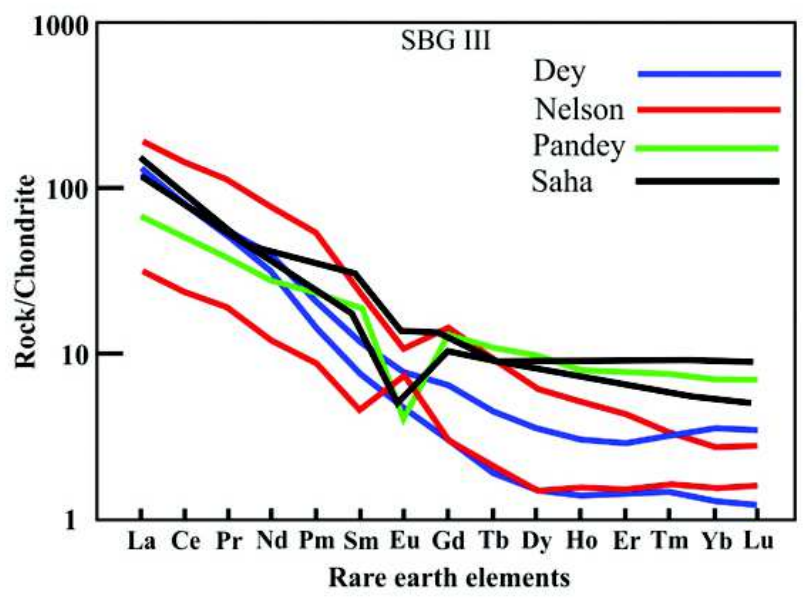

(D)

Fig. 3: A-E. REE patterns in different plutonic units in the Singhbhum Craton from different sources. Selected curves from different sources are shown. Note the variability within each unit. See text for discussion. Data source: Saha and Ray (1984), Saha (1994), Sharma et al. (1994), Tait et al. (2011), Nelson et al. (2014), Dey et al. (2017), Pandey et al. (2019)

sets of locally developed shear zones. There are two large NNE-SSW striking shear zones, the western Champua Shear Zone (CSZ) along the boundary 


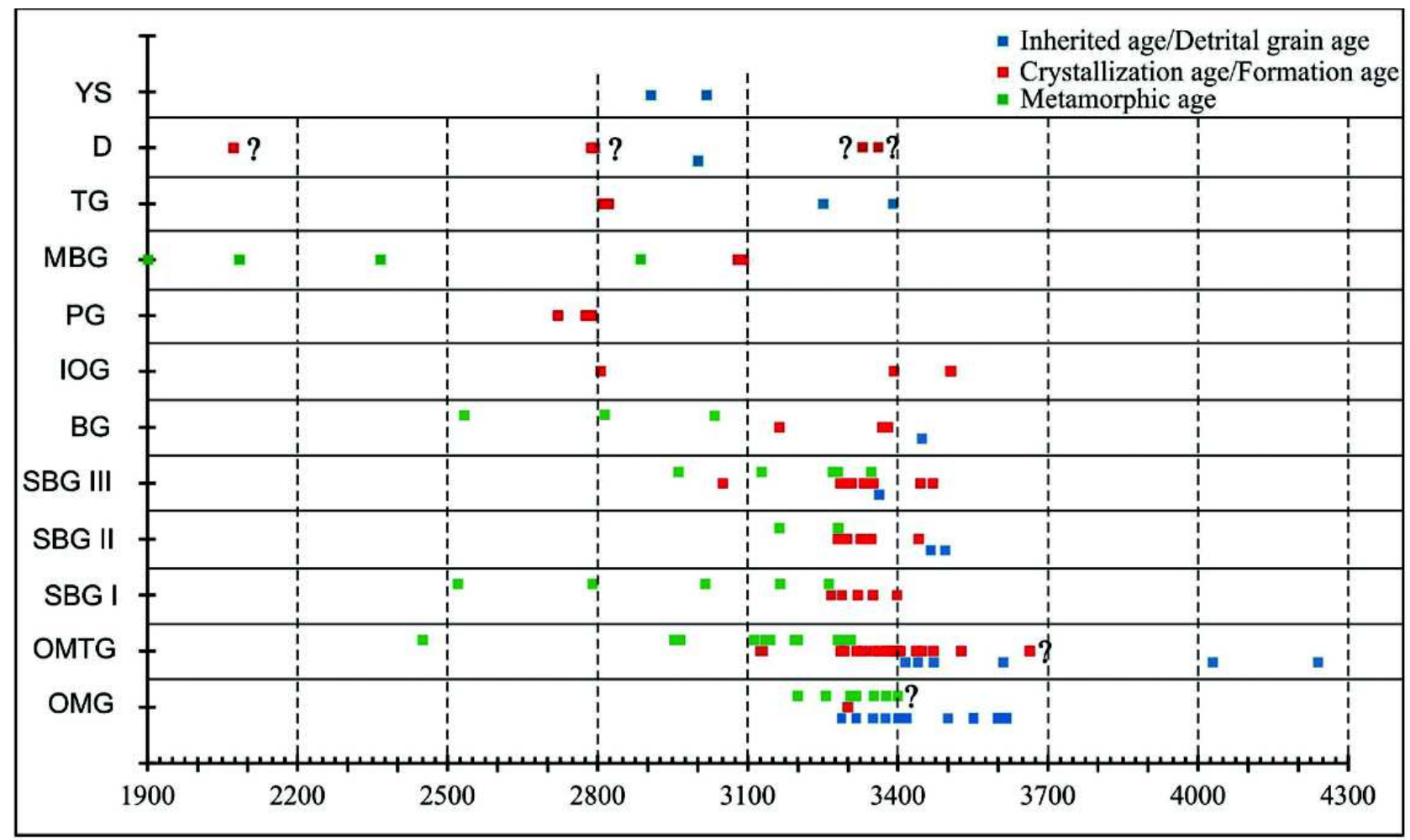

Fig. 4: Radiometric dates from the different units in the Singhbhum craton from all sources, (Data from Table 1). Mostly concordant zircon ages are shown. Rb-Sr ages are shown as metamorphic ages. D - Dhanjori Group, YS - Younger siliciclastic rocks like Keonjhar Quartzite etc. Other abbreviations are as in the text

between the OMG and the SBG, and the eastern Rairangpur Shear Zone (RSZ) within the SBG, both showing sinistral-normal (west-down) shear sense. They hypothesized that a period of crustal shortening responsible for the folding of the western Iron Ore Group belt and its accretion to the OMG-OMTG basement, was followed by extensional tectonism marked by the ascent and emplacement of the granitoids of the SBG pluton in pulses along steepdipping sinistral-normal ductile shear zones. However, the evidence is inadequate to confirm this hypothesis. Prabhakar and Bhattacharya (2013) subdivided the SBG into three types on the basis of deformation textures: Type I with low temperature deformation microstructures, common throughout the pluton; Type II with high temperature deformation microstructures, found exclusively along the western margin of the pluton; and Type III, which is sheared pegmatoidal granitoids associated with the shear zones. According to them the deformation textures developed in response to $\mathrm{D}_{4}$ shearing that is recorded also in the OMG and the OMTG. The bulk of the pluton cooled appreciably below the solidus prior to deformation, while along the western margin of the pluton the granitoids were emplaced later and were deformed while still hot.

According to Saha (1994) and Pandey et al. (2019) the SBG-Phase I is characterized by smoothly sloping REE pattern with fractioned LREE and moderately fractionated HREE and with or without Eu-anomaly (Fig. 3B). Some samples of SBG-Phase II show sloping REE patterns similar to that of OMTG, while other samples show strong Eu anomaly (Fig. 3C) (Nelson et al., 2014; Dey et al., 2017; Pandey et al., 2019). In SBG-Phase III, REE patterns show fractionated LREE, flat HREE or slightly fractionated HREE and negative Eu-anomaly, but some granodiorite samples show no Eu anomaly and a monzogranite even shows positive Eu-anomaly (Fig. 3D). Therefore, petrographically and in REE pattern different units of SBG show more variability than originally supposed by Saha (1994) (Figs. 2 and 3).

Most of the Singhbhum granitoid samples fall in low to medium pressure category (Pandey et al., 2019). The minimum value of magma temperature as 
estimated from zircon saturation temperature is $800^{\circ}+30^{\circ} \mathrm{C}$ for a porphyritic granite/trondhjemite from a Phase II pluton and $754^{\circ}+13^{\circ} \mathrm{C}$ for a non-porphyritic granite from a Phase III pluton. Pandey et al. (2019) have pointed out that all the granitoids in the SC have broadly similar geochemical characters and REE patterns which hint towards the derivation of these granitoids from chemically and mineralogically similar source(s). The negative or positive $\mathrm{Eu}$ anomalies observed in some granitoids indicate plagioclase fractionation or accumulation respectively during differentiation.

Recent geochronological data (Fig. 4) throw doubt on the three-phase chronology of the SBG as proposed by Saha and his co-workers. It is clear that there is no systematic age difference between the OMTG, the SBG Phase I, the SBG Phase II and the SBG Phase III, as these are defined now. However, there are different pulses of intrusion of granitic magma, and enclaves of older intrusions occur in the younger phases, which is reflected in the ages of zircon xenocrysts. The total period of granitic intrusion lasted from 3.52 to $3.28 \mathrm{Ga}$ and distinct pulses are dated to be at $3.52 \mathrm{Ga}$ (only in OMTG), 3.43-3.47 Ga (noted in OMTG and SBG III), 3.35-3.40 Ga (noted in OMTG only), 3.32-3.35 Ga (noted in OMTG, SBG I, SBG II and SBG III), and 3.30-3.28 Ga (noted in OMTG, SBG II and SBG III). It is also to be noted that younger 3.28-3.30 ages in the OMTG come from samples of OMTG granites and not tonalites. We are of the view that samples of granite are not to be placed within OMTG. Similarly, we recommend that the 3470 Ma trondhjemite (Pandey et al., 2019) and $3445 \mathrm{Ma}$ granite (Upadhyay et al., 2014) be taken out of Phase III and be placed within the OMTG. Olierook et al. (2019) have recommended to place the boundary between the OMTG and the SBG at ca. 3380-3365 $\mathrm{Ma}$, which marks the cessation of trondhjemite magmatism and the onset of monzogranite emplacement. However, more mineralogical, geochemical and geochronological data are necessary to fix a firm boundary between magmatic pulses having distinct compositional characteristics. It is interesting to note that the ages of detrital zircon grains in the river sand reported by Miller et al. (2018) show a prominent peak at $\sim 3.35 \mathrm{Ga}$ and smaller peaks at $\sim 3.5 \mathrm{Ga}$ and $3.1 \mathrm{Ga}$.

Pandey et al. (2019) classified the Singhbhum granitoid samples (OMTG, SBG I, SBG II, SBG III) into older and younger granitoids, and described that their $\mathrm{Sm}-\mathrm{Nd}$ isotopic compositions define linear arrays in the standard Sm-Nd isochron diagram. The apparent ages calculated from these arrays are $3344+160 \mathrm{Ma}$ and 3142+390 Ma for the older and younger granitoids respectively. The $\varepsilon_{\mathrm{Nd}(\mathrm{t})}$ values of the samples have been calculated using their respective $\mathrm{U}-\mathrm{Pb}$ zircon crystallization ages. Most of the samples have near-chondritic $\varepsilon_{\mathrm{Nd}(\mathrm{t})}$ values. The $\varepsilon_{\mathrm{Nd}(\mathrm{t})}$ values for the older granitoids (3440 Ma) range from +0.1 to +2.2 . The younger granitoids $(3263 \mathrm{Ma}$ $-3363 \mathrm{Ma}$ ) have $\varepsilon_{\mathrm{Nd}(\mathrm{t})}$ values between $\sim 0.2$ and +1.6 . A few samples have higher values of +2.7 to +5.2 .

The major relatively high grade metamorphic episode is recorded at $3.34-3.26 \mathrm{Ga}$. This is coeval with magmatic episodes in the SBG and the OMTG. Thus magmatism and metamorphism went hand in hand in the Singhbhum Craton. Younger metamorphic resettings are recorded in OMTG and SBG at 3.163.11 Ga and 3.0-2.8 Ga. This appears to be broadly synchronous with the emplacement of younger felsic plutons such as the Mayurbhanj Granite (3.1 Ga; Misra et al., 2002). Even younger dates of 2.45-2.50 Ga are sporadically recorded by zircon in the granitoids and gneisses (Upadhyay et al., 2014). Prabhakar and Bhattacharya (2013) determined CHIME ages of monazite in the SBG granitoids. The range of monazite spot ages in the three textural types recognized by them are as follows. Type I: $2973 \pm 101$ to $3255 \pm 110$ Ma (granodioritic); $3137 \pm 132$ to $3450 \pm 238 \mathrm{Ma}$ (granitic); Type II: $2920 \pm 138$ to $3339 \pm 166 \mathrm{Ma}$; and Type III: $2878 \pm 109$ to $3534 \pm 129$ Ma. They have shown that the weighted mean ages of monazites are identical for all granitoids: $3.28 \pm 0.04 \mathrm{Ga}$ for Type-I, $3.28 \pm 0.07 \mathrm{Ga}$ for Type-II, and $3.27 \pm 0.02 \mathrm{Ga}$ for TypeIII. This age is interpreted to correspond to the major deformation and metamorphic growth event. The slightly older mean monazite age of OMTG enclaves in SBG $(3306+22 \mathrm{Ma})$ provides an upper limit for the emplacement of SBG.

Dey et al. (2017) reported that the mean $\mathrm{a}_{\mathrm{Hf}(\mathrm{t})}$ values for the 3.47,3.35, and $3.30 \mathrm{Ga}$ granitoids from the SBG are $+2.1+2.8$ to $+4.8+2.8,+1.8+3.0$ to $+4.0+3.6$, and $+0.8+2.8$ to $+3.7+2.8$ respectively (Fig. $5)$, suggesting derivation from ancient crustal rocks. Because of the positive values they suggested melting of a tonalite dominated source and minor mafic source. 


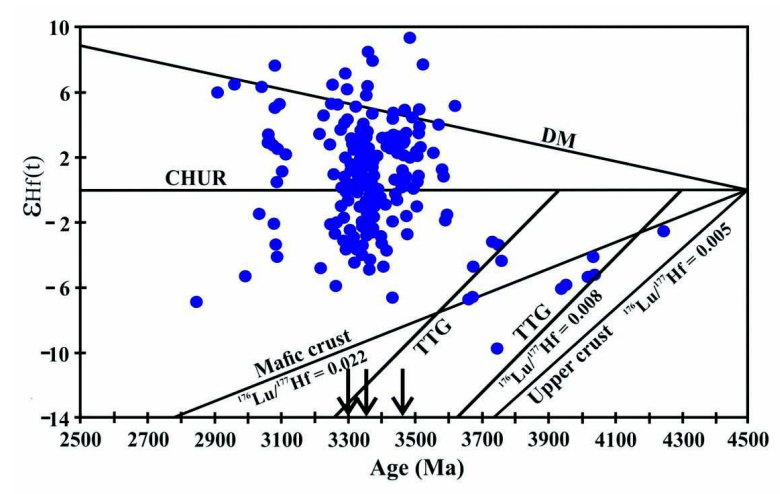

Fig. 5: $\varepsilon_{\mathrm{Hf}(\mathrm{t})}$ vs, age plots of magmatic and detrital zircon grains from the Singhbhum Craton (modified from Sreenivas et al., 2019; data source: Chaudhuri et al., 2018, Miller et al., 2018, Sreenivas et al., 2019, Pandey et al., 2019, Olierook et al., 2019). DM- Depleted mantle curve for mantle extraction at $4.5 \mathrm{Ga}$. Mafic crust (enriched reservoir) curve for ${ }^{176} \mathrm{Lu} /{ }^{177} \mathrm{Hf}=0.022$ fits the plots for the Hadean and Eoarchean zircon grains. The isotopic trajectory of the upper continental crust that formed at $4.5 \mathrm{Ga}$ is drawn for the ${ }^{176} \mathrm{Lu} /{ }^{177} \mathrm{Hf}$ ratio of 0.005 . The Hadean-Eoarchean grains $(>3.7 \mathrm{Ga})$ lie within a band around a TTG trajectory with ${ }^{176} \mathrm{Lu} /$ ${ }^{177} \mathrm{Hf}=\mathbf{0 . 0 0 8}$ that corresponds to a TTG like source that formed at $\sim 4.3-4.2 \mathrm{Ga}$. The younger Eoarchean grains lie on a trajectory that corresponds to a TTGlike source that formed at $\sim 3.95 \mathrm{Ga}$. Note that the excursion of the $\stackrel{a}{H f(t)}_{\mathbf{H}}$ towards positive values starts at 3.5 Ga. The three distinct periods of crust formation in Singhbhum are indicated by three arrows at the bottom

Pandey et al. (2019) report similar, but in general lower, mean $\varepsilon_{\mathrm{Hf}(\mathrm{t})}$ values for the Singhbhum Granite samples $(\sim 0.3+0.9$ to $+2.0+0.6)$. The latter values are near-chondritic and they argue against the recycling of large amounts of much older evolved crust as the source of granitoids of the SC and opine that the data are more consistent with a primitive near-chondritic mantle source. Pandey et al. (2019) have also reported that, samples showing high $\varepsilon_{\mathrm{Nd}(\mathrm{t})}$ values of +1.6 to +5.2 (suggesting a strongly depleted source) have near-chondritic $\varepsilon_{\mathrm{Hf}(\mathrm{t})}$ values (suggesting primitive mantle source). They have commented that $\varepsilon_{\mathrm{Nd}(\mathrm{t})}$ is determined from whole rock compositions and is sensitive to later modifications affecting the rocks. The Hf isotopic data from zircon are more robust to later modifications of the whole rock, and hence $\mathrm{Hf}$ isotopes in zircon yield more reliable measures than whole rock $\mathrm{Nd}$ isotopes.

\section{Other Granite Bodies}

The Bonai Granite ( $B G$ ) is dominantly porphyritic and also equigranular trondhjemite-granodiorite with subordinate granite (Fig. 2B) exposed west of the main SBG body. Xenoliths of trondhjemite-tonalite, banded migmatite, and older supracrustals, such as, quartzite, BIF and mafic-ultramafic rocks are common in both varieties of the BG. Chakraborty et al. (2019) reported zircon concordia age of $3370+10 \mathrm{Ma}$ as emplacement age of the Bonai Granite, and 3033+38 Ma, 2809+29 Ma, 2531+ 22 Ma as metamorphic/ hydrothermal ages.

The Mayurbhanj Granite ( $M B G$ ) forms a batholithic body, covering $\sim 1000 \mathrm{~km}^{2}$ in the southeastern side of the Singhbhum craton adjacent to the Singhbhum Shear Zone and is intrusive into the $\mathrm{SBG}$ and the IOG (Fig. 1). The $\mathrm{MBG}$ is a $\mathrm{K}_{2} \mathrm{O}$-rich suite dominantly of granite (Fig. 2B) having slightly enriched LREE with conspicuous Eu-anomaly and flat HREE pattern (Saha, 1994; Nelson et. al., 2014) (Fig. 3E); one sample shows no Eu anomaly and high HREE abundance (Fig. 3E). Zircon grains from a porphyritic granophyric granite have yielded a concordia age of $3087+3 \mathrm{Ma}$ (Nelson et al., 2014) which confirms the age $(3092+5 \mathrm{Ma})$ determined by Misra et al. (2002). Chakaraborti et al. (2019) determined an age of 3089+6 for zircon from gneissic granite belonging to the MBG suite. Therefore, the MBG is a Mesoarchean unit involved in Proterozoic deformation and metamorphism because of its proximity to the Proterozoic fold belt of North Singhbhum. More detailed work is necessary to resolve the problem of relation between the MBG and the SBG. The crystallization age of the MBG marks the time of stabilization of the craton.

A body of A-type alkali-feldspar bearing granitic gneisses within host mica schists was named as Mayurbhanj Granite by Saha (1994); it has recently been named as Bangriposi Granite by Chakraborti et al. (2019). The mafics include iron rich biotite and hastingsite. The foliation in the gneisses is mylonitic. Their REE pattern is similar to that of the MBG (Fig. 3E) with LREE enrichment, prominent Eu anomaly and flat HREE. The concordia ages of oscillatory zoned zircon grains are $3079+7 \mathrm{Ma}$ and $3115+10 \mathrm{Ma}$, similar to the age of the MBG. The $\mathrm{T}_{\mathrm{DM}}$ is $3.4 \mathrm{Ga}$ and the $\varepsilon_{\mathrm{Nd}(\mathrm{t})}$ varies between 0.5 and 1.4 . 
The Pallahara Gneiss (PG) occurs in the southwestern part of the craton as an undifferentiated gneissic terrain (Fig. 1). Having an overall compositional range from granite to quartz monzonite (Fig. 2B), it is characterized by distinct gneissic banding with alternate dark hornblende-magnetite-rich bands and light quartzo-feldspathic bands. Chemically the rocks are calc-alkaline, ferroan, weakly metaluminous granites, depleted in $\mathrm{Al}, \mathrm{Ca}$ and $\mathrm{Mg}$ and rich in LILE and HFSE and are classified as A-type granites with high $\mathrm{Y} / \mathrm{Nb}$ ratios. In the $\mathrm{Y}-\mathrm{Nb}$ discrimination diagram their plots fall in the field of within-plate granite. Zircon dating of Pallahara Gneiss fixes its time of crystallization at $\sim 2.8 \mathrm{Ga}$ (Chattopadhyay et al., 2015; Topno et al., 2018). The intrusion of Pallahara granitoids is suggested to be coeval with prominent mafic magmatism in the Singhbhum Craton (e.g., the Dhanjori mafic volcanic rocks and mafic dyke swarm) and with the Tamperkola Granite $(2809+12 \mathrm{Ma})$.

\section{Older Supracrustal Belts}

\section{Older Metamorphic Group (OMG)}

OMG occurs as enclaves of upper greenschist to amphibolite facies pelitic schists (biotite + muscovite + quartz + garnet + sillimanite), quartz-muscovite schist, quartz-magnetite-cummingtonite schist, fuchsite quartzite, banded calc-gneiss, and layered (?para-) and massive to schistose (ortho-) amphibolites spread all over the Singhbhum Granite outcrop (Fig. 1). The type area of the OMG is Champua where the OMG outcrops cover an area of $\sim 200 \mathrm{~km}^{2}$ (Fig. 1). On the basis of major element and trace element composition of the OMG biotite-muscovite schists Hofmann and Mazumder (2015) concluded that the protolith was siltstone or greywacke and the composition was similar to that of Archean greywackes and shales such as those of the Fig Tree Chert of the Barberton greenstone belt. The schists contain detrital zircon grains suggesting granitic or granite-derived sedimentary provenance of the metasediments. The REE pattern of the OMG quartzite shows high LREE enrichment with a small negative Eu anomaly and low HREE abundances, similar to that of the associated tonalite gneisses (Nelson et al., 2014). This is consistent with their derivation from principally granitoid rocks. Relatively high $\mathrm{Cr}, \mathrm{Ni}$ and $\mathrm{Mg}$ content in some schists and fuchsite quartzite suggests presence of mafic/ultramafic material also in the source area (Hofmann and Mazumder, 2015). No komatiite has been reported so far from the OMG, but from Jagannathpur area (Fig. 1) Manikyamba et al. (2015) have reported that the geochemical signatures from some samples of metamorphosed mafic rocks indicate boninitic affinity; these are associated with samples having composition of island arc tholeiites. The authors invoke magma generation in an intra-oceanic subduction zone setting and infer a depleted, refractory mantle source that has been subsequently enriched by subduction-related slabdehydration process. The rock association and the geochemical signatures suggest that the OMG outcrops represent fragments of the Archean oceanic crust, probably in an ancient (Paleoarchean) subduction system similar to, but younger than, those recorded from the Nuvvuagittuq Greenstone Belt of Canada (O'Neil et al., 2012) and Isua Greenstone Belt of Greenland (Polat et al., 2002, 2011).

The OMG was considered to be the oldest stratigraphic unit of the craton (Saha, 1994). Older $\mathrm{Sm}-\mathrm{Nd}$ isochron dating fixes the age of formation of the OMG amphibolite as $3305+60 \mathrm{Ma}$ (Sharma et al., 1994) (Table 1). ${ }^{40} \mathrm{Ar} /{ }^{39} \mathrm{Ar}$ ages of amphibole in amphibolite tallies with this age (Bakshi et al., 1987). Therefore this age is likely to represent a metamorphic age. Ages of detrital zircon grains in sedimentary rocks help in fixing the upper limit of the age of deposition. The available age data from the OMG indicate that the deposition of the supracrustal rocks may be bracketed within $\sim 3.37-\sim 3.35$ Ga (Table 1, Fig. 4). Saha et al. (2012) opined that the unimodal distribution of detrital zircon age indicates either a volcaniclastic origin of the rock or derivation by erosion of a single igneous source. U-Pb concordia age from metamorphic rutile in OMG mica schist fixes the metamorphic age as $3317+8 \mathrm{Ma}$ (Upadhyay et al., 2014). Hence not much time elapsed between the deposition and the earliest metamorphism.

The OMG supracrustal assemblage was probably formed as a greenstone-belt-type succession in a supra-subduction setting at $\sim 3.37 \mathrm{Ga}$, and it has been suggested that they represent higher grade equivalents of the Iron Ore Group of rocks (Hofmann and Mazumder, 2015).

\section{Iron Ore Group (IOG)}

The Archean volcano-sedimentary greenschist facies 
supracrustal rocks of the SC conventionally go by the name Iron Ore Group (IOG). These occur either as peripheral basins around the Singhbhum Granite batholithic complex or as keels within it (Fig. 1). The three principal volcano-sedimentary supracrustal belts, also known as the IOG basins, are: the western IOG belt (Noamundi-Jamda-Koira belt), the eastern IOG belt (Gorumahisani-Badampahar belt) and the southern IOG belt (Tomka-Daitari belt) (Fig. 1). The stratigraphic relation between the SBG and the IOG has long been a point of debate (Mukhopadhyay, 1976, 2001; Sarkar and Saha, 1977; Saha, 1994). The main reason for assigning a younger age to the IOG is the interpretation of a sandstone-conglomerate unit unconformably overlying the SBG as the basal unit of the IOG (Murty and Acharya, 1975; Mukhopadhyay, 1976). However, recent work by Ghosh et al. (2015), Ghosh et al. (2016b) and Mukhopadhyay et al. (2007, 2013, 2014, 2016) have shown that the siliciclastic rocks along the eastern margin of the western IOG belt and along the southern and southeastern margin of the southern IOG belt have an unconformable or tectonic contact with the IOG and do not constitute the basal unit of the IOG.

Recent geochronological data have confirmed the antiquity of the IOG belts. The $\sim 3380+11$ Ma age of the granite intruding the IOG at the Deo River (Nelson et al., 2014) stipulates that the BIF of the western belt cannot be younger than $\sim 3.38 \mathrm{Ga}$. Zircon grains from a tuff layer less than $1 \mathrm{~m}$ below the BIF of the western belt yield concordant age of $3392+29$ Ma (Basu et al., 2008). The age of the monzogranite near Rairangpur (3326 $\pm 5 \mathrm{Ma}$, Nelson et al., 2014) with enclaves of BIF also fixes a lower limit of the age $(>\sim 3.3 \mathrm{Ga})$ of the eastern IOG. Zircon grains from a dacitic lava immediately underlying the BIF of the southern belt (Tomka-Daitari) conformably yield a concordia age of $3507+2 \mathrm{Ma}$ and $3505+5$ (Mukhopadhyay et al., 2008, 2012; Sreenivas et al., 2019). Therefore, the deposition of the IOG supracrustals is as old as $\sim 3.5-3.4 \mathrm{Ga}$ and is of the same order as or older than the age of the OMG supracrustals. The ages of all the three IOG belts fall in this bracket.

\section{Banded Iron Formation}

It is probable that the IOG was deposited in three separate basins, which had somewhat different depositional settings, and small differences in depositional age. There are some differences in the mineralogy, geochemistry and lithological association of the BIFs in different belts, particularly between the western and the eastern belts. BIFs are more magnetite-rich in the eastern and the southern basins than in the western one. Sarkar and Gupta (2012) have summarized the differences between the three IOG basins.

In the western IOG belt, basal massive or pillowed metabasalt is followed upwards successively by chert breccias, lower phyllitic ferruginous shale/ tuff (with local thin carbonates and manganiferous units in the lower part), BIF-iron ore, and upper phyllitic shale that is ferruginous or white (Ghosh and Mukhopadhyay, 2007; Beukes et al., 2008). The chert breccia overlying the mafic lavas indicates falling sea level and aerial exposure. Structures resembling stromatolites in some of the chert clasts suggest that the breccias could have formed through solution collapse and silicification of an earlier carbonate buildup during exposure. This solution collapse breccia is overlain by a transgressive shale unit with manganiferous shale being deposited in the early stages of transgression or during low strand, which is overlain by ferruginous shale. Iron formation was deposited on top of it during maximum flooding when the basin became starved of siliciclastic input.

Trace and REE patterns with strong Eu anomalies of the iron oxide phases of the BIFs suggest exhalative hydrothermal fluids with variable, but overall high, temperatures as source for the major part of the Fe; other trace elements and REEs were contributed to the bottom seawater by diagenetic fluids and fluvial discharge to the ocean. Variable Eu anomalies in the samples indicate mixing of hydrothermal fluids of different temperatures with the bottom seawater. Insignificant $\mathrm{Ce}$ anomaly is attributed to anoxic nature of the Archean bottom sea water (Bhattacharya et al., 2007).

The overall structural trend in the different IOG supracrustal belts change from NNW-SSE in Gorumahisani-Badampahar to NE-SW near Nuasahi, ENE-WSW in Tomka-Daitari, NW-SE near Pallahara-Malayagiri and NNE-SSW in NoamundiJamda-Koira (Sarkar and Saha, 1977). Thus the trends curve round the Singhbhum Granite body, suggesting 
that the major deformation in the supracrustal belts was moulded round the granitic block (Mukhopadhyay, 1976; Sarkar and Gupta, 2012). The eastern belt probably represents a subvertical synformal keel within a granitic terrane. In the western IOG, Ghosh and Mukhopadhyay (2007) concluded that two phases of deformation have given rise to the outcrop pattern in the 'horse-shoe' structure (Fig. 6A), which is structurally a synclinorium. Its western $\operatorname{limb}$ is overturned and steep westerly dipping and the eastern limb is gently westerly dipping. On the eastern limb a second order asymmetrical fold pair congruous to the major synform is developed; on the subhorizontal short limb of this asymmetric fold pair (their eastern asymmetric anticline) third order symmetrical folds with subvertical axial planes are developed (Fig. 6B). In the southern IOG belt the first and second generation folds are co-axial and have E-W trending axial planes; the third generation folds are $\mathrm{N}-\mathrm{S}$ trending (Ghosh et al., 2010a; Bose et al., 2015). The $\mathrm{D}_{2}$ structures are thought to be related to the top-to-thenorth motion along the Sukinda Thrust.

\section{IOG Metavolcanic Rocks}

The basal parts of the supracrustal sequences in all the three IOG basins are mafic-ultramafic volcanics, often with well preserved pillow structures (Sengupta et al., 1997; Bose, 2009). The IOG volcanics often have high $\mathrm{MgO}$ (up to $13 \%$ ) with high $\mathrm{SiO}_{2}$ (up to $52 \%$ ) and some may be characterized as siliceous high magnesia basalt (SHMB). The mafic rocks in all the three IOG belts are mostly tholeiite, but basaltic andesite and andesite variants are also found. Rare ultramafic rocks with cumulate texture are present in all the three belts.

Komatiitic types with spinifex texture have been reported from several localities in the eastern belt (Chaudhuri et al., 2015; Ghosh et al., 2019). Both Al-depleted (ADK) and Al-undepleted komatiites (AUK) are present. The basal cumulate part of the komatiite is chemically similar to ADK which is characterized by subchondritic $\mathrm{Al}_{2} \mathrm{O}_{3} / \mathrm{TiO}_{2}(9.38-10.5)$ ratio and depleted HREE, elucidating presence of majorite in residuum. The upper spinifex-textured lava typically displays suprachondritic $\mathrm{Al}_{2} \mathrm{O}_{3} / \mathrm{TiO}_{2}(\sim 22-$ 28.5) ratio and enriched HREE indicating majoritefree residuum. A primitive mantle-like source is envisaged which melted at greater depth $(>300 \mathrm{~km})$ to produce the parental liquid of ADK (basal cumulate) and at shallower depth $(\sim 150 \mathrm{~km})$ to produce the AUK melt (spinifex-textured lava) (Chaudhuri et al., 2015; Ghosh et al., 2019). Sm-Nd isotopic studies suggest a mantle source with long term depletion $\left(\varepsilon_{\mathrm{Nd}}=\sim+2\right.$ to +4 ). Intrusion of $3.3 \mathrm{Ga}$ granitoid belonging to the Singhbhum Granite suite into the eastern IOG belt (Nelson et al., 2014) suggests that emplacement of these komatiites is older than $3.3 \mathrm{Ga}$. The similarity between the Singhbhum komatiite and the Barberton komatiite has been pointed out and a plume-arc geodynamic setting has been suggested.

The southerly dipping sequence in the southern IOG belt has massive or pillowed metabasalt and

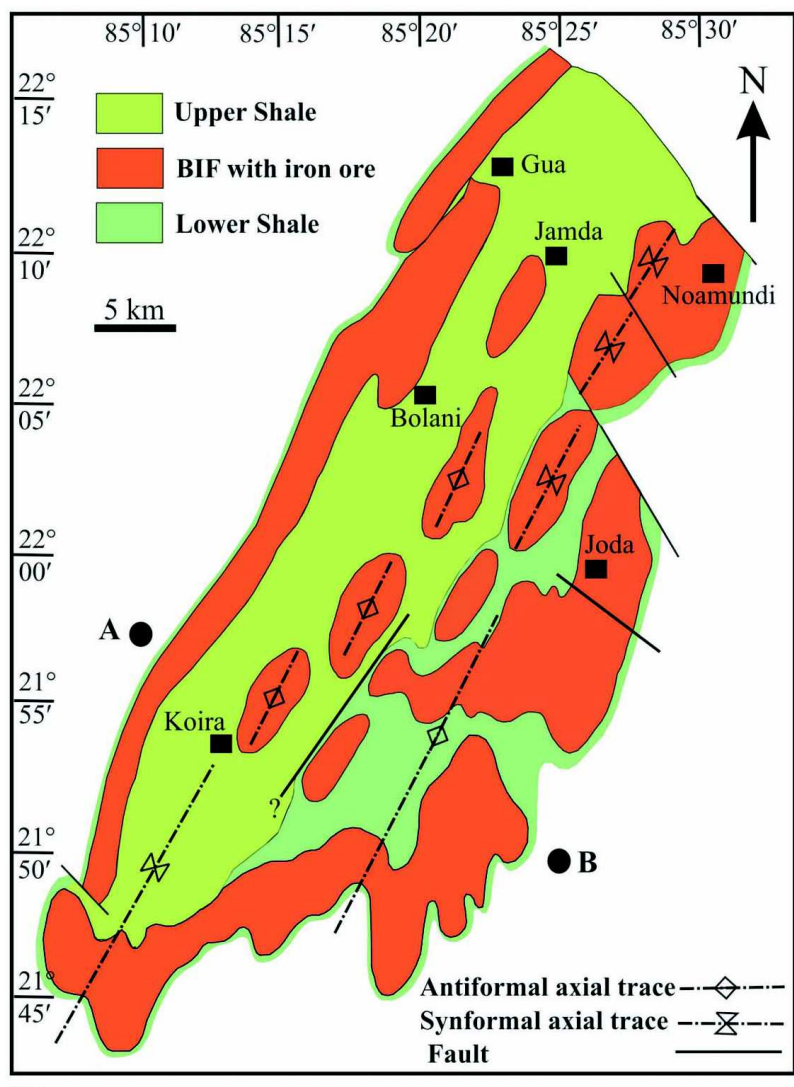

(A)

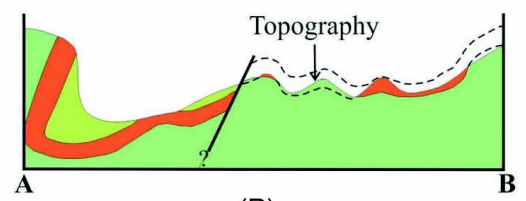

(B)

Fig. 6: (A) Generalized geological map of the western IOG. (B) Schematic cross section along A-B (in Fig. 6A). The cross section shows a regional syncline with a congruous dextral large scale fold on the eastern limb 
interbanded chert in the basal part which is overlain by a thick unit of dacitic lava flows and pyroclastic rocks followed by BIF (Mukhopadhyay et al., 2008, 2012). The dacitic volcanic unit (coherent dacitic flow and ash-poor, non-vesiculated, welded pyroclastics) is interpreted to have formed in a deep marine setting and erupted under a steam cupola (Mukhopadhyay et al., 2012). In the upper part of the volcanics there is evidence of transition from a deep water low-height volcanic chain to a shallower subaqueous eruption in an aggradational volcanic chain. This was followed by deposition of BIF. The bimodal volcanics association and the trace elements and REE characteristics of the volcanic units in the southern IOG are similar to the rocks in Phanerozoic suprasubduction arc-fore arc settings (Mukhopadhyay et al., 2012).

The $3.5 \mathrm{Ga}$ zircons from the dacitic lava in the southern IOG belt yield a $\varepsilon_{\mathrm{Hf}(\mathrm{t})}$ value of +0.5 to +7.8 (suprachondritic $\varepsilon_{\mathrm{Hf}(\mathrm{t})}$ and radiogenic Hf isotopic composition) (Sreenivas et al., 2019) and mostly plot close to the depleted mantle (DM) curve (Fig. 5), thereby indicating that by $\sim 3.5$ Ga the depleted mantle was established under the Singhbhum Craton and was available for magma generation.

\section{Malangtoli and Jagannathpur Volcanics}

Contrasted views exist about the stratigraphic position of the Jagannathpur Volcanics (or Dungoaposi Volcanics) north of Noamundi and the Malangtoli Volcanics south of the horse-shoe closure of BIF (Fig. 1). Some workers (Saha, 1994; Singh et al., 2016; Singh et al., 2017) regard these to be younger than the IOG and lying unconformably over the latter, while others regard them to be equivalent to the basal IOG mafic volcanics (Dunn, 1940; Acharyya, 1993; Sengupta et al., 1997). The Malangtoli Volcanics with subhorizontal primary layering underlies the gently folded BIF with an overall flat attitude (Sengupta $e t$ al., 1997), and hence the field relations confirm an infra-BIF position of the Malangtoli Volcanics. There are no direct age data on the Malangtoli Volcanics. Singh et al. $(2016,2017)$ made a comparative study of the IOG Volcanics near Noamundi and the Malangtoli Volcanics and pointed out that the IOG and the Malangtoli basalts exhibit similar mineralogical composition, but the IOG volcanics samples are andesitic with a calc-alkaline affinity, while the Malangtoli Volcanics samples are basalt to andesite with tholeiitic to calc-alkaline trend. The Malangtoli Volcanics have both low- $\mathrm{MgO}$ and high-MgO varieties; some are boninitic in composition. The IOG basalts show enriched LREE and flat HREE and negative Eu-anomaly; some samples of the Malangtoli Volcanics show a similar REE pattern while the others have nearly flat LREE and HREE (Singh et al., 2016, 2017). The IOG basalts show low to moderate PGE contents (26.23-68.35 ppb of SPGE), whereas the Malangtoli basalts show a moderate to high concentration of PGE (SPGE $=43.01-190.43 \mathrm{ppb}$ ). The geochemical attributes point to a subductionrelated origin for both. The IOG volcanics were generated in an intra-oceanic arc setting, while the Malangtoli Volcanics originated in an arc to riftcontrolled back-arc setting. Arc basalts and boninites in the Malangtoli Volcanics are interpreted to be the products of juvenile subduction processes involving shallow level partial melting of mantle wedge under hydrous conditions triggered by slab-dehydrated fluid flux. High magnesian andesites and the $\mathrm{Nb}$-enriched basalts represent the intermediate and mature stages of subduction respectively (Singh et al., 2017) and slab-melting and mantle wedge hybridization processes were involved in their melt generation. The IOG volcanic rocks are modelled to have been derived by $<1-1 \%$ partial melting of garnet lherzolite whereas the Malangtoli basalts were generated by $3-<10 \%$ partial melting from spinel to garnet lherzolite. Banerjee et al. (2016), on the basis of tectonic discrimination diagrams, supported the idea that the Malangtoli Volcanics have island arc tholeiitic affinity; in other words they were erupted in a suprasubduction setting.

The Jagannathpur Volcanics exposed near Noamundi along the eastern margin of the western IOG belt dips gently towards SW and show gentle domes and basins structure. Some of the volcanics resemble boninites with high $\mathrm{MgO}$, low Ti/Zr and high $\mathrm{Zr} / \mathrm{Y}$. The Jagannathpur and Malangtoli Volcanics are apparently undeformed, but the AMS studies (Mukherji et al., 2004; Ghosh et al., 2010b) reveal that they share the same magnetic fabric as the IOG mafic rocks and on this ground the three are correlated.

\section{Younger Supracrustal Belts}

\section{Dhanjori Basin}

Dhanjori basin is situated in the north-eastern corner 
of the Singhbhum Craton (Fig. 1). It is a NW-SE trending, elongate basin that is caught up in the deformation of the Mesoproterozoic orogeny represented by the North Singhbhum Mobile Belt. The Dhanjori succession, predominantly consisting of volcanics and volcaniclastic and siliciclastic sediments, unconformably overlies the granitoids of the SBG pluton. The Dhanjori Group has been subdivided into Upper and Lower Formations (Mazumder and Sarkar, 2004; De et al., 2015). The Lower Dhanjori Formation consists of pebbly phyllite, quartzite and thin conglomerates with minor mafic-ultramafic intrusions and the Upper Dhanjori Formation consists of volcanics and volcaniclastic rocks along with quartzites and phyllites. The Phuljhari Formation disconformably underlies the polymictic conglomeratequartzite of the Lower Dhanjoris. The basal Dhanjoris are profusely intruded by the $\sim 3.1$ Ga old Mayurbhanj Granite Acharyya et al. (2010). Hence, at least the lower part of the Dhanjori Group is older than $\sim 3.1$ Ga.

On the basis of sediment characteristics and Sm$\mathrm{Nd}$ isotopic data De et al. (2015) suggested proximal sources and poorly mixed provenance with both mafic and felsic rocks. They further suggested a provenance in a juvenile felsic Andean-type magmatic arc situated on the Archean basement. Mazumder (2006) observed that the magmatic component of the Dhanjori Formation represents a Large Igneous Province (LIP), and Mazumder and Arima (2009), on the basis of major, trace, rare earth elements composition, and selected elemental ratios $(\mathrm{Nb} / \mathrm{Th}, \mathrm{Zr} / \mathrm{Nb}, \mathrm{Nb} / \mathrm{Y}$, and $\mathrm{Zr} / \mathrm{Y}$ ) from the Upper Dhanjori volcanics and volcaniclastics and the sedimentological and stratigraphical characteristics of the interbanded metasedimentary rocks, inferred an intracontinental rift setting for Dhanjori volcanism and sedimentation. Bose (2009) also inferred extensional tectonics for the Dhanjori basin.

Earlier whole rock Sm-Nd isochron dating led to contradictory results (Roy et al., 2002; Misra and Johnson, 2005) (Table 1). Acharyya et al. (2010) carried out $\mathrm{U}-\mathrm{Pb}$ dating of zircon grains from the acid tuff in the Phuljhari Formation. The U-Pb dates from the zircon grains were highly discordant and no precise age estimate can be made. The upper intercepts of the discordia lines with the concordia curve give ages of 3330+58 and 3358+110 Ma. Since the Mayurbhanj
Granite with probable age of $\sim 3.1$ Ga intrudes (see Table 1) the Phuljhari Formation the Dhanjori Group ought to be $>3.1$ Ga old.

The Simlipal Basin has a circular outcrop pattern and is surrounded by the SBG or undifferentiated granite (Fig. 1). The volcano-sedimentary sequence of the basin overlies the Singhbhum and Kaptipada Granites and IOG of the Badampahar belt. It starts with basal quartz pebble conglomerate, orthoquartzite and feldspathic quartzite; the basal units are overlain by a volcanic pile (spilitic lavas and tuffs), with three intercalated bands of cross bedded quartzites (Iyengar and Banerjee, 1964). The origin and age of the basin remains unresolved. Along the flanks a suite of gabbro-anorthosite and the Mayurbhanj Granite intrude into the volcanics (Saha 1994), testifying to its pre-MBG status. The Simlipal Volcanics is correlated with the Dhanjori Group mainly because of similar lithological associations in the two basins and their close proximity, but definite evidence about the correlation is lacking. Naqvi and Rogers (1987) floated the idea that the Simlipal basin may be an astrobleme or impact crater, but so far no evidence of any meteorite impact has been found.

\section{Other Metasedimentary Sequences}

\section{Mahagiri Quartzite, Keonjhar Quartzite, Mankaharchua Quartzite, Malayagiri Supracrustals, Devgarh Quartzite}

Extensive siliciclastic rocks are exposed along the western boundary of the Singhbhum Granite pluton separating the latter from the western IOG belt (Ghosh et al., 2015) (Fig. 1). The $\sim 1.5-\mathrm{km}$-thick siliciclastic succession, exposed between Joda and Keonjhargarh, has been named as Keonjhar Quartzite (Ghosh et al., 2016b). Similar rocks extend from west of Keonjhar along the south-eastern margin of the SBG up to Sukinda where the rocks are named as Mahagiri Formation or Mahagiri Quartzite (Mukhopadhyay et al., 2012, 2014) (Fig. 1). Siliciclastic rocks are also exposed north of Pallahara near Mankaharchua lying unconformably over the Malangtoli Volcanics (Fig. 1). $\mathrm{U}-\mathrm{Pb}$ ages determined from detrital zircons from samples of sandstone coming from a large area extending from Keonjhar to Mahagiri and Mankaharchua cluster between 3950 to $2909 \mathrm{Ma}$ (Mukhopadhyay et al., 2014; Sreenivas et al., 2019). 
The age of the granitic basement on which the sandstone lies is $3.29 \mathrm{Ga}$, and this sandstone is intruded by $\sim 2.8 \mathrm{Ga}$ old granitoids at the Mahagiri Range (Mukhopadhyay et al., 2014). Thus the time of deposition of theMahagiri Quartzite must be between 2.91 and 2.8 Ga. Paleo- and Mesoarchean ages (3510$3176 \mathrm{Ma})$ are dominant among the detrital zircon population. Some Eoarchean grains have ages of 39503601 Ma.

Ghosh et al. (2016b) inferred a continental interior setting for the sandstones. Several geochemical proxies indicate their highly matured and recycled nature and they have a mixed source of predominantly granodioritic and primitive mafic rocks belonging to a differentiated felsic upper continental crust (UCC). Evidence also points to the presence of both unweathered and deeply weathered source rocks. The rare earth element patterns of the siliciclastics are similar to those of the post-Archean shales. Recycling and intracrustal fractionation processes imply craton stabilization and confirm the existence of a Mesoarchean continental crust comparable to the post-Archean UCC from other parts of the world (Ghosh et al., 2016b). The detrital uraninite grains in Mahagiri and Keonjhar Quartzites suggest the existence of highly felsic and K-rich (richer than TTG) granodiorite-granite-monzogranite suites of rocks older than $2.9 \mathrm{Ga}$ in the Singhbhum craton. Dey et al. (2017) have reported superchondritic $\varepsilon_{\mathrm{Hf}(\mathrm{t})}$ values ( +1 to +8.75$)$ from detrital zircons in the Mahagiri Quartzite, suggesting predominantly juvenile mantle source. The radiogenic Hf isotopic ratio in the depleted mantle source is interpreted to be typical of I-type granite that largely forms in islandarc type accretionary settings.

The siliciclastic sediments are underlain by pyrophyllite-bearing paleosol (Bandyopadhyay et al., 2010) formed on the surface of the 3.29 Ga old (Tait et al., 2011) granite. This is the oldest documented Archean paleosol in the Indian shield (Mukhopadhyay et al., 2014). Soft-sediment deformation in the paleosol near the contact with the overlying sandstone indicates that the paleosol was wet at the onset of deposition of the overlying siliciclastic sediments. The soil type suggests alternation of very wet and very dry climate (Bandyopadhyay et al., 2010). Geochemical evidence indicates that oxidative weathering occurred in the original upper soil profile, and the paleosol was formed before the deposition of sediments. On the other hand, presence of detrital uraninite and pyrite at the base of the siliciclastic sequence points to low surface oxygen condition during the time of deposition. Hence, Mukhopadhyay et al. (2014) have invoked that a short-lived atmospheric oxygenation event occurred about 600 Ma prior to the Great Oxidation Event. This probably took place because of the presence of organisms capable of oxygenic photosynthesis.

The BIF-bearing Malayagiri sequence unconformably overlies the $\sim 2.8$ Ga old Pallahara Gneiss (Saha, 1994) and the zircon grains from a dacite in the supracrustal sequence have a concordant age of 2806+6 Ma (Nelson et al., 2014). Furthermore, the age of the youngest detrital zircon population from quartz-kyanite-muscovite schist is $2788+25 \mathrm{Ma}$ (Chattopadhyay et al., 2015). Chattopadhyay et al. (2015) concluded that the deposition of the Malayagiri supracrustals was between 2.79 and $2.42 \mathrm{Ga}$ and the rocks were affected by three major metamorphic events at $\sim 2.42 \mathrm{Ga}, 0.98-0.94 \mathrm{Ga}$, and 0.57-0.54 Ga. Hence, the Malayagiri supracrustals are younger than Keonjhar Quartzite or Mahagiri Quartzite.

\section{Kolhan Group}

The main Kolhan basin, covering an area of $\sim 600$ $\mathrm{km}^{2}$, extends from Chaibasa to Noamundi, and straddles the boundary between the IOG of the western belt and the Singhbhum Granite (Dunn, 1940) (Fig. 1). The Kolhan sequence unconformably overlies the Singhbhum Granite and the Iron Ore Group, and is the youngest stratigraphic unit in the Singhbhum craton.

Bandopadhyay and Sengupta (2004) suggested that the shale-dominated succession of the Kolhan sequence was deposited in continental rift setting. The lower red and purple sandstones with beds/lenses of conglomerates were deposited by shallow, ephemeral braided streams. The dominantly parallel-bedded sandstones with sheet-like geometry of the sandstone beds and rare channel-form structures imply that much of the sediments is a product of sheet floods, while the overlying thick and extensive shale was deposited in lacustrine environment. Petrography and geochemistry of the shales and CIA (Chemical Index of Alteration) values of the Kolhan siliciclastics, suggest deposition in plate interior, either at stable 
continental margin or in intracratonic basin. Mukhopadhyay et al. (2006) have described the Kolhan succession as a siliciclastic shelf to deepwater carbonate platform succession. They suggested that the Kolhan succession represents a syn-rift to post-rift succession, which is equivalent to the terminal Mesoproterozoic carbonate platform successions developed in other parts of peninsular India. It represents an event of major transgression and relative sea level rise.

Ghosh et al. (2015) reported pervasive deformation features from the Kolhan basin and pointed out that the north-western boundary of the basin is marked by a major thrust fault, named as the Chaibasa thrust, with top-to south displacement along which older Archean succession was thrusted over the younger Kolhan rocks.

\section{Darjing Group}

The region north of the Bonai Granite extending up to the Gangpur Group is occupied by a sequence of lowgrade metamorphic rocks (Fig. 1) for which Mahalik (1987) proposed the name Darjing Group. Alternative stratigraphic groupings of the rocks of this region have been proposed by Sen (2001) and Naik (2001). The differences in interpretations are to be sorted out by detailed mapping and facies analysis of the sediments. The maximum age of the Darjing Group is constrained by the $3129 \pm 10 \mathrm{Ma}$ age of the youngest detrital zircon grains (Chakraborty et al., 2019). It is intruded by the Tamperkola Granite having an age of $2809 \pm 12$ (Bandyopadhyay et al., 2001). So the age of the Darjing Group is between 3.1 and $2.8 \mathrm{Ga}$.

Chakraborty et al. (2019) used the term Upper Bonai Group for the supracrustal sequence that includes the Darjing Group and extends up to the SBG pluton. Two major metamorphic episodes are recorded in the rocks - an earlier $\mathrm{M}_{1}$ episode produced garnet $_{1}$ and staurolite, $\mathrm{M}_{2}$ produced garnet ${ }_{2}$ which grew at the expense of staurolite. The estimated PT conditions are: $\mathrm{M}_{1}-520^{\circ}-580^{\circ} \mathrm{C}, 4.8 \mathrm{~kb} ; \mathrm{M}_{2}-650^{\circ} \mathrm{C}$, $7.4 \mathrm{~kb}$. The Upper Bonai Group is intruded by garnetbearing granites which are deformed.

\section{Supracrustal Rocks with Debatable Stratigraphic Status}

The low grade phyllites, tuffs and quartzites at the
NW corner and along the northern part of the western edge of the SBG pluton have a debatable stratigraphic status. Ghosh et al. (2015) inferred the presence of two thrust sheets within the phyllites and quartzites of this area (Fig. 7A). The upper boundary of this stack of thrust sheets is the Singhbhum Shear Zone (SSZ) of the North Singhbhum Mobile Belt (NSMB), and lower boundary is with the Kolhans. According to this interpretation, this group of siliciclastic rocks is older than the Dhanjoris. Bhattacharya and Mahapatra (2008) grouped the rocks unconformably lying over the northern and northwestern boundary of the Singhbhum Granite in two units, the Bisrampur Formation and the Nayadih Formation, which were thrusted over by the Iron Ore Group and the Dhanjori Group in the north (Fig. 7B). This is an interesting hypothesis, but it needs to be confirmed by more detailed structural mapping over a larger region and geochronological work.

\section{Ultramafic-Mafic-Anorthosite Suites}

Ultramafic-mafic-anorthosite suites mostly occur along the eastern side of the Singhbhum Craton as a number linear discontinuous bodies extending from south of Haludpukur to Nuasahi and Sukinda (Fig. 1). Ultramafic rocks are also present at Jojohatu, south of the Ongarbira Volcanics and also east of the Bonai Granite (Fig. 1). The ultramafic rocks of SukindaNuasahi are intrusive into the Singhbhum Granite and are intruded by the Mayurbhanj granite and granophyre (Saha, 1994). Augé et al. (2003) reported $3123+7,3122+5$ and $3119+6$ Ma zircon ages from the gabbroic suite at Nuasahi, and $3205 \pm 280 \mathrm{Ma}$ Sm-Nd isochron age of the gabbroic suite. Anorthositic rocks are found near Gorumahisani and Nuasahi. At Sukinda and Nuasahi the intrusive body is a layered ultramafic body, with ultramafics in the lower part and gabbro with anorthosite in the upper part, but there is no direct age determination of the emplacement of ultramafics. The ultramafic rocks are picrite, lherzolite, orthopyroxenite, harzburgite, dunite and chromitite and characteristically show adcumulate texture. The parent magma is boninitic or siliceous high-Mg basalt (SHMB) (Khatun et al., 2014; Mondal, 2009, Mondal et al., 2019). The geochemistry and REE patterns suggest that the boninitic parental magma was generated by second-stage melting of a metasomatized depleted mantle source in a supra-subduction setting. The spidergrams of trace elements in gabbro samples 

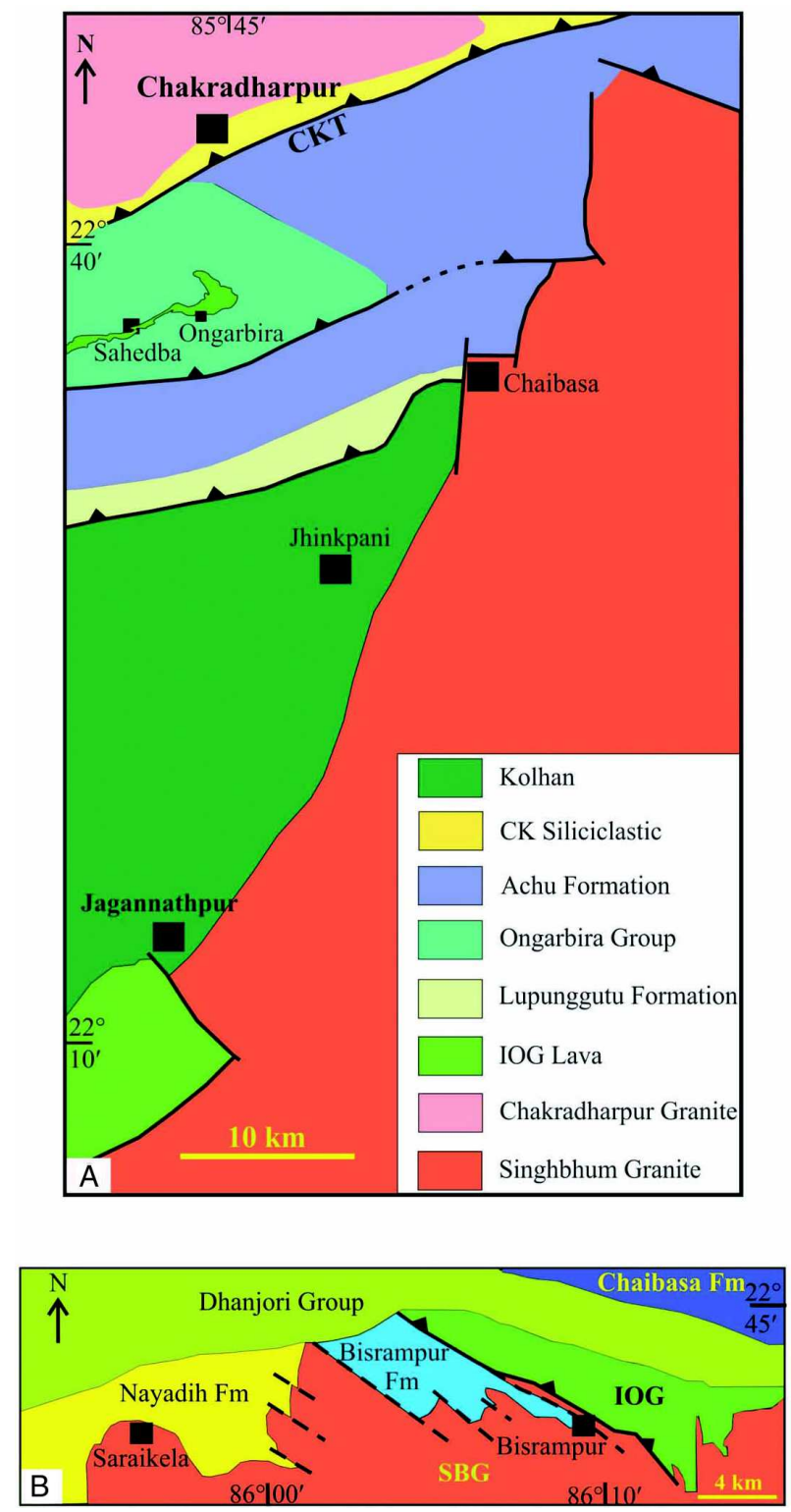

Fig. 7: (A) Geological map of the northwestern edge of the Singhbhum Granite pluton, showing the stacked thrust sheets over the Kolhan Group (after Ghosh et al., 2015). (B) Interpreted stratigraphic set up at the northwestern corner of the Singhbhum Granite pluton (after Bhattacharya and Mahapatra, 2008)

show negative $\mathrm{Nb}$-, $\mathrm{Th}-, \mathrm{Zr}-$, and $\mathrm{Hf}$-anomalies indicating derivation from a depleted mantle (Mondal and Zhou, 2010). $\left[_{\mathrm{Nd}(\mathrm{t})}\right.$ value of $+2.63+0.88$ for the high-Mg gabbroic suite is consistent with an origin from a long-term depleted source region. The high Os concentrations (and IPGE-rich character in general) of the studied Archean chromitites are supportive of the idea of a high degree of melting of a previously depleted upper mantle source domain for generating the parental melts of chromite-bearing ultramafic suites (Mondal et al., 2004, 2006). This points to the presence of early Archean subcontinental lithospheric mantle (SCLM) domain beneath the $\mathrm{SC}$ which represents the stable residue after extensive melt extraction in the Archean. Os model age calculation from the chromites indicate that depletion from the primitive mantle to form the SCLM started as early as $\sim 3.7 \mathrm{Ga}$, nearly 500 to $600 \mathrm{Ma}$ earlier than the crystallization of chromite (Mondal et al., 2007). This is consistent with the conclusions derived earlier from the isotopic data from granitoid rocks. Alternatively, the parent melts may have come from depleted zones surviving within the convective mantle. Mondal et al. (2007) hypothesized that the parental magma of the ultramafic suite was produced in a supra-subduction setting and intruded the volcanosedimentary greenstone belts at shallower crustal levels. They envisioned a process of early subduction of sections of melt-depleted subchondritic oceanic lithospheric mantle with large degree melt extraction events and concomitant major crust building processes during middle-to late-Archean in the Singhbhum Craton. A supra-subduction setting has recently been suggested to explain the existence of boninite-like metabasalts in the 3.7 Ga old Isua Greenstone Belt in Western Greenland (Polat et al., 2002; Polat and Frei, 2005). Mondal (2009) has proposed that similarity of the sub-continental lithospheric mantle characteristics of the Singhbhum Craton and the Zimbabwean craton suggest that South Africa and India were parts of the same supercontinent in early Archean (Myers, 1995).

\section{Newer Dolerite Dyke Swarm}

Spectacular dyke swarms called the Newer Dolerite traverse the Singhbhum Granite pluton and occasionally occur within the Bonai Granite, Kaptipada Granite and Mayurbhanj Granite. Such dyke swarms are interpreted to represent the plumbing systems of LIPs which are deeply eroded to expose the feeder dykes (Ernst, 2014). Hence, they are useful for identifying Large Igneous Provinces (LIPs) and for paleogeographic reconstruction (Srivastava et al., 2016). The dominant trend of near vertical dykes within the Singhbhum Granite is NNE-SSW to NE-SW; subsidiary trends are NW-SE and E-W. The dimension of the dykes varies from a few tens of $\mathrm{cm}$ to one $\mathrm{km}$ in width and from a few hundred metres up to $20 \mathrm{~km}$ in length. 
The dykes are mostly made up of quartz dolerite, and locally of norite, peridotite and lamprophyre. Rarely acid rocks, such as, micropegmatitic dolerite, microgranite, xenolithic granophyre and leucogranophyre are also associated with the dolerite along the margins of the dykes.

Recently, $\mathrm{Pb}-\mathrm{Pb}$ baddeleyite ages of $1766+1$ and 1765+1 Ma were obtained for the WNW'ly trending swarm (Shankar et al., 2014). Dykes of this trend distinctly cut across dykes of other orientations and possibly represent one of the youngest swarms in the region. Coeval mafic magmatism has been found in North China Craton, Kimberley Basin in Australia, Rio de Plata Craton, Uruguay and Brazilian craton. This may point to the assembly of supercontinent Columbia. Kumar et al. (2017) recognized three distinct trends in the Newer Dolerite dyke swarm: NNE-SSW, NW-SE and WNW-ESE. Based on crosscutting field relations the NNE'ly trending swarm appears to be the oldest. Six dykes from this swarm have yielded $\mathrm{Pb}-\mathrm{Pb}$ baddeleyite ages ranging between $2764 \mathrm{Ma}$ and $2760 \mathrm{Ma}$, with a weighted mean age of $2762+2$ Ma. Baddeleyite from the NE-SW to ENEWSW trending Kaptipada swarm has been dated by Srivastava et al. $(2016,2019)$. They give a weighted mean of $2251+2 \mathrm{Ma}$ for the ${ }^{207} \mathrm{~Pb} /{ }^{206} \mathrm{~Pb}$ ages of the samples.

The mean paleomagnetic pole position obtained from dykes of the NNE-SSW trending swarm by Kumar et al. (2017) is $14^{\circ} \mathrm{N}, 78^{\circ} \mathrm{E}$. This is comparable to one of the pole positions obtained earlier by Verma and Prasad (1974). The similarity of determined paleolatitudes and the broad contemporaneity of the 2762,2800,2752 Ma magmatic events in the Singhbhum Craton, the Pilbara Craton of Australia, and the Kaapvaal Craton of South Africa led Kumar et al. (2017) to suggest that these three cratons were assembled together in the Neoarchean time to form the Vaalbara Supercraton.

Based on field relations and U-Pb dating the Newer Dolerite dykes have been grouped by Srivastava et al. (2019) in seven distinct swarms. These range in age from $\sim 2.80 \mathrm{Ga}$ to $1.76 \mathrm{Ga}$, and include the following:

1. Keshargaria swarm $-\sim 2.8 \mathrm{Ga}$, NE-SW trending.

2. Ghatgaon swarm - 2.76-2.75 Ga, NNE-SSW to NE-SW trending, most extensive swarm.

3. Keonjhar swarm - Between 2.76 and $2.26 \mathrm{Ga}$, early-Paleoproterozoic, NNE-WSW to E-W trending, radiating pattern.

4. Kaptipada swarm - 2.26 Ga, NE-SW to ENEWSW trending, radiating pattern.

5. Bhagamunda swarm - Between 2.26 and 1.77 Ga, middle-Paleoproterozoic, NNW-SSE to NWSE trending, radiating pattern.

6. Pipilia swarm - $1.77 \mathrm{Ga}, \mathrm{WNW}-\mathrm{ESE}$ trending.

7. Barigaon swarm - $<1.77 \mathrm{Ga}$, late Paleoproterozoic, N-S to NNE-SSW trending, radiating pattern.

Except for the Pipilia swarm which has similar age as the Dalma Volcanics of the NSMB, none of the other dyke swarm can be linked to a specific episode of mafic magmatic activity within the Singhbhum Craton. The Kaptipada swarm (2.26 Ga) and the Pipilia swarm (1.76 Ga) are closely matched with two swarms of comparable age in the Dharwar Craton, and Srivastava et al. (2019) have tentatively identified two swarms of similar ages in the Bastar Craton. They have, therefore, concluded that by at least 2.26 Ga the Dharwar, Bastar and Singhbhum cratons were joined together, and two LIPS existed at the two above mentioned times covering all the three cratons. They further suggested that the trends of $2.26 \mathrm{Ga}$ dykes in the three cratons display a radiating pattern and they converge to define a possible plume centre at the northeastern end of the Dharwar-Bastar join. The $1.76 \mathrm{Ga}$ swarms in the three cratons, on the other hand, display parallel trends. They had also correlated the NNE-SSW trending Ghatgaon swarm (2.76-2.75 Ga) of the Singhbhum Craton with the WNW-ESE trending Keshkal swarm $(2.7 \mathrm{Ga})$ of the Bastar Craton, and the dyke trends converge to a possible plume centre situated SE of the Bastar Craton. However, in the absence of paleomagnetic data, these reconstructions would remain speculative.

\section{Window on the Hadean and the Eoarchean Earth}

Paleoarchean ages dominate among the determined ages from different granitoid units making up the SC. But detrital zircon grains in the supracrustal rocks 
and xenocrystic zircon grains in the granitoid gneisses provide information about the existence of older crust. The existence of Eoarchean continental crust was first inferred by Goswami et al. (1995) from Eoarchean ages of $3628+72,3591+64$, and $3583+50$ Ma from cores of detrital zircon grains.

The oldest reported Hadean ages from the SC are the concordant ages $(\sim 4.03$ to $\sim 4.24 \mathrm{Ga})$ of xenocrysts of zircons in the OMTG $(\sim 3.4 \mathrm{Ga}$ old $)$ from near Champua (Chaudhuri et al., 2018); these have thin rims with Eoarchean $(\sim 3.8$ to $\sim 3.9 \mathrm{Ga})$ ages (Table 1). The cores of other xenocrysts yield Eoarchean crystallization ages $(\sim 3.7$ to $\sim 3.6 \mathrm{Ga})$. The Hadean xenocrysts have nonradiogenic ${ }^{176} \mathrm{Hf} /{ }^{177} \mathrm{Hf}$ initial compositions $(0.27995+0.0009$ to $0.28001+$ $0.0007)$, and the $\varepsilon_{\mathrm{Hft}]}$ values range from -2.5 to -5.2 , suggesting that they originated from Hadean enriched reservoir (Fig. 5). Time integrated $\varepsilon_{\mathrm{Hf}[\mathrm{t}]}$ compositional array of the Hadean xenocrysts indicates that a mafic protolith with ${ }^{176} \mathrm{Lu} /{ }^{177} \mathrm{Hf}$ ratio of $\sim 0.019$ was reworked during $\sim 4.2-4.0 \mathrm{Ga}$. The isotopic data suggest that the separation of such an enriched reservoir from chondritic mantle took place at $4.5+$ $0.19 \mathrm{Ga}$, that is, soon after (after $\sim 40 \mathrm{Ma}$ ) the accretion of the Earth. This mafic source may represent an enriched residual mafic crust generated from a partially solidified magma ocean. More radiogenic yet subchondritic ${ }^{176} \mathrm{Hf} /{ }^{177} \mathrm{Hf}$ values for some other $\sim 3.6$ to $\sim 3.7 \mathrm{Ga}$ old zircon grains from OMTG have values like $\varepsilon_{\mathrm{Hf(t)}}=-1.5$ to -6.6 , and $\sim 3.4 \mathrm{Ga}$ zircons have $\varepsilon_{\mathrm{Hf(t)}}=-0.4$ to $-3.7 . \sim 3.4$ and $\sim 3.3$ Ga old zircons from the Singhbhum Granite have $\varepsilon_{\mathrm{Hf}(\mathrm{t})}=-0.3$ to -4.7 . These have been interpreted by Chaudhuri et al. (2018) to indicate that the enriched Hadean reservoir subsequently underwent mixing with depleted-mantlederived juvenile magma during Eoarchean to Paleoarchean.

Sreenivas et al. (2019) reported Eoarchean detrital zircons (3950-3601 Ma crystallization age) from Mesoarchean $(\sim 3.0 \mathrm{Ga})$ Mahagiri Quartzite in the southeastern part of the SC (Table 1). Their $\mathrm{T}_{\mathrm{DM}}$ ranges from 4.51 to $4.15 \mathrm{Ga}$. They also show nonradiogenic $\varepsilon_{\mathrm{Hf(t)}}$ values ranging from $-3.37+0.5$ to $-9.75+0.4$ suggesting an enriched source. The authors interpret that the Eoarchean zircon grains represent crust generated by recycling of Hadean felsic crust formed at $\sim 4.3$ to $4.2 \mathrm{Ga}$ and $\sim 3.95 \mathrm{Ga}$ (Fig. 5).
Miller et al. (2018) carried out U-Pb age determinations of detrital zircon grains in modern river sediments of the Baitarini River basin that is wholly contained within the SC. The data for grains which are less than $5 \%$ discordant are principally grouped in three clusters: $3.62-3.55(5 \%), 3.50-3.22(87 \%)$ and 3.10-3.06 Ga (6\%). One grain (1.3\% discordant) shows a Hadean age of 4015+9 Ma (Table 1). Single stage Lu-Hf model ages of these grains range from 4.29 to $3.10 \mathrm{Ga}$. Since Lu-Hf model age is an estimate of the time when the protolith of the rock left the uniform chondritic reservoir the above model ages suggest the existence of Hadean, Eoarchean and younger crust. The $\varepsilon_{\mathrm{Hft} \mathrm{t}]}$ values show a range; $67 \%$ values are positive scattered above and below the depleted mantle growth curve, and 33\% values are negative. This indicates contribution from both depleted mantle and enriched crustal sources. The Hadean grain $(4.015 \mathrm{Ga})$ had an $\varepsilon_{\mathrm{Hf}[\mathrm{t}]}$ value of -5.3 suggesting an enriched, likely crustal, influence on the parent magma.

All the data sources have yielded similar results and point to the same conclusions. Collectively, the data show a contiguous spread of zircon ages from 4.2 to $3.6 \mathrm{Ga}$ (Fig. 5). Therefore, there is ample evidence of early mantle depletion and formation of enriched crust during the Hadean and Eoarchean time in the Singhbhum craton. Olierook et al. (2019) have drawn attention to the interesting fact that $4.24 \mathrm{Ga}$ and 4.03-4.01 Ga ages obtained in Singhbhum are similar to two peaks in the global Hadean zircon record (Griffin et al., 2014; Marchi et al., 2014).

\section{Evolutionary History and Geodynamic Considerations}

There is an intense debate on the geodynamics of crust formation during Hadean and Archean times (Hawkesworth et al., 2010, 2017; Griffin et al., 2014). Basically there are two contending hypotheses; (1) plume-driven, and (2) subduction-driven development. Some hold the view that some form of subduction and plate tectonics was an important process contributing to crust formation and it started from Eoarchean and even Hadean times (Polat et al., 1998, 2002, 2016; Nutman et al., 2007; Reimink et al., 2014; Kaczmarek et al., 2016). Others suggest that plume-related processes were mainly responsible for the Archean crust formation (Puchtel et al., 1998; 
Polat et al., 2006; van Kranendonk, 2010; Moyen, 2011; Johnson et al., 2014, 2017; van Kranendonk et al., 2004, 2015). For the Singhbhum Craton also a number of models have been proposed. These include: plume origin (Sharma et al., 1994), repeated diapiric rise of felsic magma, punctuated by sedimentation in basins peripheral to the domical central part of the craton (Nelson et al., 2014), crustal melting in response to plume driven magmatic underplating in an oceanic plateau setting (Dey, 2017), and island arc type accretionary setting (Saha et al., 2004; Mukhopadhyay et al., 2008, 2012; Tait et al., 2011; Manikyamba et al., 2015; Singh et al., 2016).

The evidence for the existence of Hadean and Eoarchean continental crust that is $>500 \mathrm{Ma}$ older than the oldest preserved continental crust in the Singhbhum Craton has already been discussed. However, the felsic rocks of such ancient age are completely reworked and recycled attesting to a highly unstable tectonic regime. Hafnium isotopic data from zircons in Jack Hills supracrustal rocks (Yilgarn Craton) (Blichert-Toft and Albarede, 2008; Kemp et al., 2010), the Acasta Gneisses (Slave Craton) (Iizuka et al., 2009; Bauer et al., 2017), Greenland (Fisher and Vervoort, 2018), the Isua Supracrustal Belt (Greenland) (Bennet et al., 1993; Caro et al. 2006) and the Nuvvuagittuq Supracrustal Belt (Canada) (O'Neil et al., 2008, 2012), provide evidence of early mantle depletion and existence of enriched crust during Hadean to Eoarchean. In the Singhbhum Craton too evidence of early mantle depletion and existence of an enriched reservoir during Hadean and Eoarchean come from zircon grains older than $3500 \mathrm{Ma}$; these display exclusively subchondritic (negative) $\varepsilon_{\mathrm{Hf}(\mathrm{t})}$ values (Fig. 5), signifying the existence of nonchondritic enriched reservoir as early as $\sim 4.2 \mathrm{Ga}$. It is hence inferred that the source reservoirs of the rocks with Hadean and Eoarchean zircon grains had separated from the chondritic material quite early in the Earth's history.

Chaudhuri et al. (2018) proposed that in the ${ }_{\mathrm{Hf}[\mathrm{t}]}$ - Age diagram a straight line (isotopic growth curve) corresponding to ${ }^{176} \mathrm{Lu} /{ }^{177} \mathrm{Hf}=0.019$ fits the plots of the Hadean zircon grains (Fig. 5). This corresponds to an enriched source area like a 'mafic protocrust' that separated from the chondritic reservoir at $\sim 4.5$ $\mathrm{Ga}$, soon after ( $\sim 40 \mathrm{Ma})$ the accretion of the Earth. They envisaged that the enriched residual mafic magma was generated in an essentially non-plate tectonic way from a partially solidified magma ocean analogous to KREEP (K, REE, P) rich basalt below a lunar anorthositic crust (Kemp et al., 2010). It has also been suggested that the primordial crust that covered the Hadean Earth when the magma ocean solidified was made up of komatiites and related rocks (Santosh et al., 2017, and references therein). Hadean and Eoarchean zircon crystallized from minor silicic melts produced by differentiation or remelting of this pre- $\sim 4.2$ Ga juvenile mafic protocrust. The presence of Paleoarchean granites with subchondritic $\varepsilon_{\mathrm{Hf}(\mathrm{t})}$ values (Fig. 5) signifies that this enriched reservoir was sustained till the Paleoarchean.

For the Eoarchean zircons from the SC, the Hf isotopic ratios are more radiogenic but still subchondritic. While Chaudhuri et al. (2018) are of the view that the second stage of melt generation during Eoarchean was from the mafic protocrust (enriched source) modified by its interaction with juvenile (more radiogenic) mantle melt, Sreenivas et al. (2019) proposed that the plots of Hadean and Eoarchean zircons fit into two broad trajectories with ${ }^{176} \mathrm{Lu} /{ }^{177} \mathrm{Hf}=0.008$, and these correspond to TTGlike sources that formed at $\sim 4.3-4.2 \mathrm{Ga}$ and $\sim 3.95 \mathrm{Ga}$ respectively (Fig. 5); that is, according to them the Eoarchean zircons represent crust generated by recycling of Hadean felsic crust. There is no unequivocal evidence to choose between the two hypotheses. Sreenivas et al. (2019) remarked that the continuous involvement of the enriched reservoirs between 4.2 and $3.6 \mathrm{Ga}$ is not consistent with magma generation by plate tectonic processes.

High heat production in the Archean time probably led to more rapid mantle convection which was responsible for quick recycling of the Hadean protocrust preventing its preservation. Hence the mafic Hadean protocrust in the Singhbhum craton has not survived and has been recycled and assimilated into younger voluminous TTG magma. The amphibolite enclaves within the OMTG and the SBG may represent the remnants of the oldest mafic protocrust or these enclaves could represent a modified mafic component developed from interactions between ancient enriched reservoir and mantlederived juvenile mafic magma and were preserved as melting residuum of the mafic protolith from which granitoid magma was generated. A definite conclusion 
will have to wait till we get more geochemical and isotopic data from the enclaves. Because of the quick assimilation or recycling into the mantle of the Hadean protocrust it has been suggested that the early depleted mantle was likely to be transient (Bennet et al., 1993; Zeh et al., 2008).

From $\sim 3.6-3.5 \mathrm{Ga}$ a shift in the isotopic composition of $\mathrm{Hf}$ is noticed, marked by upward excursion of $\varepsilon_{\mathrm{Hf}(\mathrm{t})}$ plots towards suprachondritic values (Fig. 5). This signifies that the early enriched reservoir underwent modifications through serial mixing with depleted mantle-derived juvenile magma. A large number of samples of Paleoarchean zircons have suprachondritic ${ }^{176} \mathrm{Hf} /{ }^{177} \mathrm{Hf}$ values which attests to the importance of magma generation from a depleted mantle reservoir at this time (Dey et al., 2017). Therefore, a major depletion of the mantle and concomitant extensive continental crust formation started in the SC from 3.5 Ga. A separate depleted reservoir which was probably complementary to the ancient enriched reservoir existed under the Singhbhum craton in the Paleoarchean. Chaudhuri et al. (2018) suggested that the $\sim 3.4 \mathrm{Ga}$ komatiites of the eastern IOG belt with $\varepsilon_{\mathrm{Nd}(\mathrm{t})}=+2$ to +4 are the most plausible direct representatives of depleted lower mantle below the SC.

The evidence for Paleoarchean and Eoarchean mantle depletion also comes from the study of IOG mafic-ultramafic rocks and the chromitites of Sukinda and Nausahi (Mondal, 2009 and references therein). Mondal et al. (2007) concluded on the basis of Sm$\mathrm{Nd}$ isotopic composition that the high-Mg mafic rocks of the IOG in Sukinda and Nausahi and the OMG amphibolites are nearly contemporaneous. Their $+\mathrm{ve}$ $\varepsilon_{\mathrm{Nd}(\mathrm{t})}$ ratios suggest a long-term depleted source region. They proposed suprasubduction setting for the generation of the parental magma that produced the ultramafic suite. The ${ }^{187} \mathrm{Os} /{ }^{188} \mathrm{Os}$ ratios of the Sukinda and Nausahi chromitites are nonradiogenic and on the basis of the isotopic data the authors suggested that a subcontinental lithospheric mantle (SCLM) started to form beneath the Singhbhum craton in early Archean $(\sim 3.7 \mathrm{Ga})$ through depletion of a primitive mantle and grew through the Archean eon. An alternative possibility is that the depleted mantle region could have remained within the convecting mantle for a few hundred million years before being added to the SCLM beneath the Singhbhum Craton.
During the Paleoarchean period the central part of the Singhbhum Craton was built up through successive pulses of granitic magmatism. Felsic magmatism at $3.52 \mathrm{Ga}, 3.47-3.43 \mathrm{Ga}$, and 3.40-3.35 Ga produced the TTG-type suite of the OMTG. The ages indicate that some parts of OMTG are older than the OMG and some are younger intrusions (cf. Roy and Bhattacharya, 2012). Younger pulses at 3.323.35 Ga, and 3.31-3.28 Ga produced the voluminous granitic magma that engulfed the OMTG and produced the composite pluton of Singhbhum Granite. This was also a period of major metamorphism in the terrain (3.34-3.26 Ga). Younger tectonothermal events also affected the craton.

On the basis of the geochemical parameters and the $+\mathrm{ve} \varepsilon_{\mathrm{Hf}(\mathrm{t})}$ values of the SBG samples studied by them Dey et al. (2017) concluded that the $3471 \mathrm{Ma}-$ old tonalite was produced by shallow melting of a juvenile mafic source, derived from a depleted mantle, and the 3347 Ma-old granite was produced by hightemperature melting of a heterogeneous juvenile source of tonalites and mafic rocks at low crustal depths and the younger 3304 Ma-old granite was produced by high-pressure melting of tonalitedominated source with short crustal residence. There was no direct involvement of the mantle in the origin of any of these granitoid rocks. Regarding tectonic setting Dey et al. (2017) proposed crustal reworking driven by episodic plume-related mafic-ultramafic magma underplating and intraplating in an oceanic plateau setting as a model for the origin of the Singhbhum granitoids. Melting of mafic crust at different depths within the thick oceanic crust led to variation in composition of the different pulses of felsic magmatism. Bédard (2006) has discussed how successive plume activities may build up a thick volcanic crust which in its lower part is metamorphosed into amphibolite. Successive underplating of magma melts the amphibolite at the base of the crust to produce successive generations of tonalite melt. The older generations of tonalites are extensively remobilized and also contribute to the younger tonalites.

In contrast to the plume hypothesis, the geochemical signatures within a 3290 Ma-old weakly peraluminous TTG body within the SBG pluton led Tait et al. (2011) to infer a volcanic arc paleotectonic setting at a crustal margin. Furthermore, the 
geochemistry of the Mg-rich OMG volcanics with boninitic affinity point to their genesis in intra-oceanic subduction setting. From the geochemistry of sedimentary rocks sourced from OMG-OMTG Saha et al. (2004) inferred that the OMG-OMTG formed a subduction-related arc complex at $\sim 3.3 \mathrm{Ga}$. The OMG and the IOG in the three belts are broadly contemporaneous or formed within a time interval of about $100 \mathrm{Ma}$ (between 3.5-3.4 Ga). The IOG belts are thought to have formed in a supra-subduction setting (Basu et al., 2008; Mukhopadhyay et. al, 2012; Singh et al., 2015, 2017), with the deposition of the supracrustals variously regarded to be in rifted arc, back-arc or fore-arc basins.

Saha et al. (2004) concluded on the basis of REE abundances and Sm-Nd isotopic characteristics that the sandstones from the Birtola Formation of the Darjing Group were derived from the OMG amphibolites and OMTG tonalites. They pointed out that the strong $\mathrm{Nb}$-Ta depletion relative to the primitive mantle suggests the sandstones to be derived from subduction-related magmatic arc sources. The low $\mathrm{Nb} / \mathrm{Ta}$ and high $\mathrm{Zr} / \mathrm{Sm}$ ratios of these sandstones are identical to those for the Archean tonalitetrondhjemites that require, based on recent traceelement partitioning results, their protoliths to have formed by subduction melting of low magnesium amphibolites or metamorphosed hydrous basalts. Saha et al. (2004) inferred that subduction-accretion processes operated during the mid-Archean in the Singhbhum Craton. For the mid-Archean Dhanjori Group, De et al. (2015) suggested a sedimentary provenance in a felsic Andean-type magmatic arc.

Malangtoli Volcanics which are regarded as the basal unit of the eastern IOG sequence are characterized as arc basalt-boninite-high magnesian andesite-Nb enriched basalt (Singh et al., 2016, 2017). Their geochemical attributes reflect different stages of subduction and genesis of the volcanics in forearc to rifted backarc setting in a region proximal to active continental margin.

From geochemical considerations Mukhopadhyay et al. (2008) suggested that the southern IOG belt is akin to an ophiolite formed in a supra-subduction setting. They suggested a non-plume source for the volcanics and their formation in an extending oceanic-arc-forearc geodynamic setting.
Geochemistry of the southern BIFs suggests their deposition in close proximity to spreading centres that might have developed over a rifted arc.

The geochemical characters of the komatiites in the eastern IOG were interpreted by Chaudhuri et al. (2015) to indicate mantle plume activity in an oceanic/arc setting. Later, Chaudhuri et al. (2017) on the basis of an enlarged data set suggested geochemical affinity of the Singhbhum komatiites with other non-arc, plume related oceanic basalts pointing to their emplacement in oceanic tectonic settings.

In summary, the Singhbhum Craton is built up multiple pulses of discrete mantle plume events, episodic plume-related mafic-ultramafic magma underplating and intraplating, and repeated crustal reworking to generate the felsic magmas (Olierook et. al., 2019). These mantle plumes probably operated in a stagnant-lid tectonic regime at least in the Hadean and Eoarchean times, but appear to be punctuated by discrete subduction zone events as witnessed by the deposition of several volcano-sedimentary sequences in supra-subduction setting. The Singhbhum Craton possibly records a transition from plume-driven stagnant lid tectonics to active subduction-related tectonics at $\sim 3.5 \mathrm{Ga}$ (Sreenivas et al., 2019). While the OMG supracrustals were incorporated within the intrusive granitic bodies and were co-deformed and co-metamorphosed at 3.3-3.2 Ga, the peripheral IOG basins were accreted to the OMTG-SBG composite pluton. The timing of this accretion is not precisely defined (Prabhakar and Bhattacharya, 2013). The time of major metamorphism at $3.34-3.26 \mathrm{Ga}$ is at present the best estimate.

It is generally believed that the Earth was once covered by a magma ocean (Elkins-Tanton, 2012). When the magma ocean solidified he Hadean Earth was covered by a mafic protocrust. This formed the lid and stagnant-lid (or single-lid) tectonics was likely to be the common mechanism at this stage (Stern, 2018). Bédard (2018) has discussed that the stagnantlid behaviour was likely to be periodically disturbed because of perturbations in the Earth's heat generation/loss balance, eventually triggering mantle overturns. Archaean basalts were derived from fertile mantle in overturn upwelling zones (OUZOs), which were analogous to, but larger than and more longlived than, post-Archean plumes. Early cratons/ 
continents probably formed above OUZOs as large volumes of basalt and komatiite were delivered for protracted periods by the mantle upwells (?plumes), allowing basal crustal anatexis to generate tonalite melt, along with the complementary generation of eclogite to pyroxenite restites (Bédard, 2006), periodic restite delamination, and coupled development of continental crust and sub-continental lithospheric mantle. Periodic mixing and homogenization hindered the development of depleted mantle. Only after the establishment of true negative buoyancy-driven subduction, leading to the sequestration of the subducted slab at the core-mantle boundary, could the long-lasting depleted mantle develop (Bédard, 2018). When this transition took place in geological time is a debatable point.

Stern (2018) discussed the conditions to be satisfied for plate tectonics to operate. One of the important conditions is that the lithosphere must be denser than the underlying asthenosphere; another one is that the subducting slab must be strong enough to remain intact in subduction zones. In Archean times, the relative thickness of oceanic crust (buoyant) is likely to be more and the relative thickness of lithospheric mantle (dense) less, so that the density of total lithosphere is likely to be less than the critical density necessary for sinking. Moreover, as the Archean mantle was hotter it would be weaker. The other important condition is the presence or development of zones of lithospheric weakness that are $\sim 1000 \mathrm{~km}$ long or longer. Large bolide impact may cause such zones of weakness in early Earth. Numerical modelling, taking these points into consideration, shows that subduction-driven plate tectonics could not have occurred in the Archean; or, if subduction did occur, it would be short-lived and of limited length (Stern, 2018, and references therein). In the early stage of Earth history, plate tectonic and single lid tectonic regimes may have alternated. This might have been the scenario at the Singhbhum Craton during Eoarchean,

Gerya et al. (2015) and Davaille et al. (2017) showed through thermo-mechanical modelling and experiments that subduction may be plume-induced. The arrival of a sufficiently large, hot and long-lived mantle plume could render strong and dense negatively buoyant oceanic lithosphere weak enough to produce new self-sustaining subduction zones, which marked the beginning of plate tectonics. However, only the most energetic mantle plumes with large plume head and considerable temperature excess were able to sufficiently weaken the lithosphere enough to initiate subduction. The formation of such plume-driven oceanic plateaus in the Archean eon (Dey et al., 2017) could have triggered the onset of subduction and plate tectonics.

These points have to be taken into consideration in building up a geodynamic model for evolution of the Singhbhum Craton. In particular, it is to be critically assessed whether the supra-subduction settings inferred for the supracrustal belts on the basis of geochemical attributes were short-lived and followed by further plume activities in a stagnant-lid set-up. A viable geodynamic model for the evolution of the Singhbhum Craton tightly constrained by geological, geochemical, isotopic and geochronological data is yet to come up.

The Singhbhum Craton had stabilized by $\sim 3.1-$ 3.0 Ga. By this time it had emerged as a landmass so that paleosols could form on the surface and terrestrial siliciclastic sediments (Keonjhar Quartzite, Mahagiri Quartzite etc.) could be deposited on top of them. The craton had cooled and had become sufficiently rigid to permit the formation of the intracontinental rift basin in which the Dhanjori sediments and volcanics were laid down. The continental freeboard was at its maximum at this time (Bandopadhyay et al., 2010; Mazumder et al., 2012a, 2012b). The anorogenic Mayurbhanj Granite $(\sim 3.1 \mathrm{Ga})$ and the slightly younger Tamperkola Granite $(\sim 2.8 \mathrm{Ga})$ and Pallahara Gneiss $(\sim 2.8 \mathrm{Ga})$ are the last major granite magmatisms in the craton. The rift-controlled sedimentation, volcanism and plutonism along the margins of the craton may be tied up with the early stage of basin development in the North Singhbhum Mobile Belt bordering the craton. The Chaibasa Formation in the NSMB overlies the Dhanjoris with structural parallelism, but probably with a hiatus (Mukhopadhyay, 1976; Mazumder et al., 2012a). This represents a major marine transgression marking the beginning of the main stage of sedimentation and basin development in the NSMB. We speculate that the Kolhan sedimentation may also represent a marine incursion along the western edge of the craton. But the age of the Kolhans is not yet precisely defined, so this idea would remain in the realm of speculation. 
The formation of different sets of Newer Dolerite dyke swarms from $2.76 \mathrm{Ga}$ to $<1.77$ Ga marks the end-Archean tensional regime in the craton, which may also be related to pre-orogenic stage of basin development in the NSMB. The Singhbhum craton remained a stable block since then and subsequent activity shifted to the Mesoproterozoic orogenic belt (NSMB) which bordered the craton in the north, east

\section{References}

Acharyya S (1993) Greenstones from Singhbhum craton, their Archaean character, oceanic crustal affinity and tectonics. Proceedings of the Indian Academy of Sciences-Earth and Planetary Sciences India section A 63 211-211

Acharyya S Gupta A and Orihashi Y (2010a) New U-Pb zircon ages Paleo-Mesoproterozoic TTG gneisses of the Singhbhum Craton, eastern India. Geochemical Journal 44 81-88

Acharyya S, Gupta A and Orihashi Y (2010b) NeoarcheanPaleoproterozoic stratigraphy of the Dhanjori basin, Singhbhum Craton, Eastern India: And recording of a few $\mathrm{U}-\mathrm{Pb}$ zircon dates from its basal part Journal of Asian Earth Sciences 39 527-536

Augé T, Cocherie A, Genna A, Armstrong ,R Guerrot C, Mukherjee M M and Patra R N (2003) Age of the Baula PGE mineralization (Orissa, India) and its implications concerning the Singhbhum Archaean nucleus Precambrian Research 121 85-101

Bakshi A K, Archibald D, Sarkar S and Saha A (1987) ${ }^{40} \mathrm{Ar}-{ }^{39} \mathrm{Ar}$ incremental heating study of mineral separates from the early Archean east Indian craton: implications for the thermal history of a section of the Singbhum Granite batholithic complex Canadian Journal of Earth Sciences 24 1985-1993

Bandopadhyay P, Chakrabarti A, Deomurari M and Misra S (2001) $2.8 \mathrm{Ga}$ old anorogenic granite-acid volcanics association from western margin of the Singhbhum-Orissa Craton, eastern India Gondwana Research 4 465-475

Bandopadhyay P C, Eriksson P G and Roberts R J (2010) A vertic paleosol at the Archean-Proterozoic contact from the Singhbhum Orissa craton, eastern India Precambrian Reseach 177 277-290

Bandopadhyay P C and Sengupta S (2004) The Paleoproterozoic Supracrustal Kolhan Group in Singhbhum Craton, India and the Indo-African Supercontinent, Gondwana Research (Gondwana Newsletter Section) 7 1228-1235 and west. In the south, the Eastern Ghat Belt was sutured to the Singhbhum craton probably during Grenvillian orogeny or later during Pan-African orogeny. At its waning stage, a major shear zone (Eastern Indian Tectonic Zone) cut across the eastern boundary of the craton and the Mesoproterozoic orogenic belt.

Banerjee M, Ray J, Nandy S, Manikyamba C, Paul M, Chakraborty D and Eslami A (2016) Experimental studies to constrain parental magma of Malangtoli volcanics from Singhbhum craton of the eastern Indian shield Journal of the Geological Society of India $\mathbf{8 8}$ 245-255

Basu A Bandyopadhyay P Chakrabarti R and Zou H (2008) Large 3.4 ga algoma-type BIF in the Eastern Indian Craton Geochimica Cosmochimica Acta Supplement 72 A59

Basu A, Sharma M and Premo W (1996) U-Pb age of an older Metamorphic Group mica schist: earliest terrain of the eastern Indian Craton. Recent Researches in Geology and Geophysics of the Precambrians, Hindustan Publication Corporation, New Delhi, India 16 93-102

Bauer A M, Fisher C M, Vervoort J D and Bowring S A (2017) Coupled zircon $\mathrm{Lu}-\mathrm{Hf}$ and $\mathrm{U}-\mathrm{Pb}$ isotopic analyses of the oldest terrestrial crust, the $>4.03 \mathrm{Ga}$ Acasta Gneiss Complex Earth and Planetary Science Letters 458 37-48

Bédard J H (2006) A catalytic delamination-driven model for coupled genesis of Archean crust and subcontinental lithospheric mantle Geochimica Cosmochimica Acta 70 1188-1214

Bédard J H (2018) Stagnant lids and mantle overturns: Implications for Archaean tectonics, magmagenesis, crustal growth, mantle evolution, and the start of plate tectonics Geoscience Frontiers 9 19-49

Beukes N J, Mukhopadhyay J and Gutzmer J (2008) Genesis of high-grade iron ores of the Archean Iron Ore Group around Noamundi, India Economic Geology 103 365-386

Bhattacharya H, Chakraborty I and Ghosh K K (2007) Geochemistry of some banded iron-formations of the archean supracrustals, Jharkhand-Orissa region, India Journal of Earth System Science 116 245-259

Bhattacharya A, Das H H, Bell E, Bhattacharya A, Chatterjee N, Saha L and Dutt A(2016) Restoration of Late NeoarcheanEarly Cambrian tectonics in the Rengali orogen and its environs (eastern India): The Antarctic connection Lithos $263190-212$ 
Bhattacharya H and Mahapatra S (2008) Evolution of the Proterozoic rift margin sediments-North Singhbhum Mobile belt, Jharkhand-Orissa, India Precambrian Research 162 302-316

Blackburn W and Srivastava D (1994) Geochemistry and tectonic significance of the Ongarbira metavolcanic rocks, Singhbhum District, India Precambrian Research 67 181206

Blichert-Toft J and Albarède F (2008) Hafnium isotopes in Jack Hills zircons and the formation of the Hadean crust Earth and Planetary Science Letters 265 686-702

Bose M K (2009) Precambrian mafic magmatism in the Singhbhum craton, eastern India Journal of the Geological Society of India 73 13-35

Bose S, Guha S, Ghosh G, Das K and Mukhopadhyay J (2015) Tectonic juxtaposition of crust and continental growth during orogenesis: example from the Rengali Province, eastern India Geoscience Frontiers 6 537-555

Caro G, Bourdon B, Birck J L and Moorbath S (2006) Highprecision ${ }^{142} \mathrm{Nd} /{ }^{144} \mathrm{Nd}$ measurements in terrestrial rocks: constraints on the early differentiation of the Earth's mantle Geochimica Cosmochimica Acta 70 164-191

Chakraborti T M, Ray A, Deb G K, Upadhyay D and Chakrabarti $\mathrm{R}$ (2019) Evidence of crustal reworking in the Mesoarchean: Insights from geochemical, $\mathrm{U}-\mathrm{Pb}$ zircon and $\mathrm{Nd}$ isotopic study of a 3.08-3.12 Ga ferro-potassic granite-gneiss from north-eastern margin of Singhbhum Craton, India Lithos 330-331 16-34

Chatterjee N, Banerjee M, Bhattacharya A and Maji A (2010) Monazite chronology, metamorphism-anatexis and tectonic relevance of the mid-Neoproterozoic Eastern Indian Tectonic Zone Precambrian Research 179 99-120

Chattopadhyay S, Upadhyay D, Nanda J K, Mezger K, Pruseth K L and Berndt J (2015) Proto-India was a part of Rodinia: evidence from Grenville-age suturing of the Eastern Ghats Province with the Paleoarchean Singhbhum Craton Precambrian Research 266 506-529

Chaudhuri T, Mazumder R and Arima M (2015) Petrography and geochemistry of Mesoarchaean komatiites from the eastern Iron Ore belt, Singhbhum craton, India, and its similarity with 'Barberton type komatiite' Journal of African Earth Sciences 101 135-147

Chaudhuri T, Satish-Kumar M, Mazumder R and Biswas S (2017) Geochemistry and Sm-Nd isotopic characteristics of the Paleoarchean Komatiites from Singhbhum Craton, Eastern India and their implications Precambrian Research 298 $385-402$
Chaudhuri T, Wan Y, Mazumder R, Ma M and Liu D (2018) Evidence of Enriched, Hadean Mantle Reservoir from 4.24.0 Ga zircon xenocrysts from Paleoarchean TTGs of the Singhbhum Craton, Eastern India Scientific reports 87069. DOI:10.1038/s41598-018-25494-6.

Crowe W A, Nash C R, Harris L B, Leeming P M and Rankin L R (2003) The Geology of the Rengali Province: implications for the tectonic development of Northern Orissa, India Journal of Asian Earth Sciences 21 697-710

Davaille A, Smrekar S E and Tomlinson S (2017) Experimental and observational evidence for plume-induced subduction on Venus Nature Geoscience 10 349-355

De S, Mazumder R, Ohta T, Hegner E, Yamada K, Bhattacharyya T, Chiarenzelli J, Altermann W and Arima M (2015) Geochemical and $\mathrm{Sm}-\mathrm{Nd}$ isotopic characteristics of the Late Archaean-Palaeoproterozoic Dhanjori and Chaibasa metasedimentary rocks, Singhbhum craton, E. India: Implications for provenance, and contemporary basin tectonics Precambrian Research 256 62-78

Dey S, Topno A, Liu Y and Zong K (2017) Generation and evolution of Palaeoarchaean continental crust in the central part of the Singhbhum craton, eastern India Precambrian Research 298 268-291

Dunn J A (1940) The stratigraphy of south Singhbhum Memoir of the Geological Survey of India 63 303-369

Elkins-Tanton L T (2012) Magma Oceans in the Inner Solar System Ann Rev Earth and Planetary Science 40 113-139

Ernst R E (2014) Large Igneous Provinces. Cambridge University Press, Cambridge, 653

Fisher C M and Vervoort J D (2018) Using the magmatic record to constrain the growth of continental crust-The Eoarchean zircon Hf record of Greenland Earth and Planetary Science Letters $\mathbf{4 8 8}$ 79-91

Gerya T, Stern R J, Baes M, Sobolev S and Whattam S (2015) Plume-induced subduction initiation triggered plate tectonics on Earth Nature 527 221-225

Ghosh G, Bose S, Das K, Dasgupta A, Yamamoto T, Hayasakam Y, Chakrabarti K and Mukhopadhyay J (2016a) Transpression and juxtaposition of middle crust over upper crust forming a crustal scale flower structure: insight from structural, fabric, and kinematic studies from the Rengali Province, eastern India Journal of Structural Geology $\mathbf{8 3}$ 156-179

Ghosh G, Bose S, Guha S, Mukhopadhyay J and Aich S (2010a) Remobilization of the southern margin of the Singhbhum Craton, eastern India during the Eastern Ghats orogeny Indian Journal of Geology 80 97-114 
Ghosh S, De S and Mukhopadhyay J (2016b) Provenance of> 2.8 Ga Keonjhar Quartzite, Singhbhum Craton, Eastern India: Implications for the nature of Mesoarchean upper crust and geodynamics Indian Journal of Geology 124 $331-351$

Ghosh G, Ghosh B and Mukhopadhyay J (2015) PalaeoarchaeanMesoproterozoic sedimentation and tectonics along the west-northwestern margin of the Singhbhum Granite body, eastern India: a synthesis Geological Society of London, Memoirs 43 121-138

Ghosh G, Kumari S, Patil S K, Mukhopadhyay J and Ray A (2010b) Superposed deformation fabrics in the Precambrian metabasic rocks of the Iron Ore Group, Singhbhum craton, Eastern India: Evidences from anisotropy of magnetic susceptibility studies Journal of Structural Geology 32 249-261

Ghosh G and Mukhopadhyay J (2007) Reappraisal of the structure of the Western Iron Ore Group, Singhbhum craton, eastern India: Implications for the exploration of BIF-hosted iron ore deposits Gondwana Research 12525 532

Ghosh S and Sengupta S (1987) Structural history of the Singhbhum shear zone in relation to the northern belt, Geological Evolution of Peninsular, India Researches in Geology 13 31-44

Ghosh R, Vermeesch P, Gain D and Mondal R (2019) Genetic relationship among komatiites and associated basalts in the Badampahar greenstone belt (3.25-3.10 Ga), Singhbhum Craton, Eastern India Precambrian Research 327 196211

Goswami J N, Mishra S, Wiedenbeck M, Ray S and Saha A (1995) 3.55 Ga old zircon from Singhbhum-Orissa iron ore craton, eastern India Current Science 69 1008-1012

Griffin W L, Belousova E A, O’Neill C, O’Reilly S Y, Malkovets V, Pearson N J, Spetsius S and Wilde S A (2014) The world turns over: Hadean-Archean crust-mantle evolution Lithos 189 2-15

Hawkesworth C J, Cawood P A, Dhuime B and Kemp T I S (2017) Earth's Continental Lithosphere through Time Annual Review of Earth and Planetary Science 45 169-198

Hawkesworth C J, Dhuime B, Pietranik A B, Cawood P A, Kemp A I S and Storey C D (2010) The generation and evolution of the continental crust Journal of the Geological Society of London 167 229-248

Hofmann A and Mazumder R (2015) A review of the current status of the Older Metamorphic Group and Older Metamorphic Tonalite Gneiss: insights into the Palaeoarchaean history of the Singhbhum craton, India
Memoirs of Geological Society of London 43 103-107

Iizuka T, Komiya T, Johnson S P, Kon Y, Maruyama S and Hirata $\mathrm{T}$ (2009) Reworking of Hadean crust in the Acasta gneisses, northwestern Canada: evidence from in-situ Lu-Hf isotope analysis of zircon Chemical Geology 259 230-239

Johnson T E, Brown M, Gardiner N J, Kirkland C L and Smithies R H (2017) Earth's first stable continents did not form by subduction Nature 543 239-242

Johnson T E, Brown M, Kaus B J and VanTongeren J A (2014) Delamination and recycling of Archaean crust caused by gravitational instabilities Nature Geoscience 7 47-52

Kaczmarek M A, Reddy S M, Nutman A P, Friend C R and Bennett V C (2016) Earth's oldest mantle fabrics indicate Eoarchaean subduction Nature communications, Article No. 10655 1-7

Kemp A, Wilde S, Hawkesworth C, Coath,C Nemchin A, Pidgeon R, Vervoort J and DuFrane S (2010) Hadean crustal evolution revisited: new constraints from $\mathrm{Pb}-\mathrm{Hf}$ isotope systematics of the Jack Hills zircons Earth and Planetary Science Letters 296 45-56

Khatun S, Mondal S K, Zhou M F, Balaram V and Prichard H M (2014) Platinum-group element (PGE) geochemistry of Mesoarchean ultramafic-mafic cumulate rocks and chromitites from the Nuasahi Massif, Singhbhum Craton (India) Lithos 205 322-340

Kumar A, Parasharamalu V, Ravi Shankar and Besse J (2017) Evidence for a Neoarchean LIP in the Singhbhum craton, eastern India: Implications to Vaalbara supercontinent Precambrian Research 292 163-174

Mahalik N K (1987) Geology of rocks lying between Gangpur Group and Iron Ore Group of the Horse shoe syncline in North Orissa Indian Journal of Earth Sciences 14 73-83

Mahapatro S, Pant N, Bhowmik S, Tripathy A and Nanda J (2012) Archaean granulite facies metamorphism at the Singhbhum Craton-Eastern Ghats Mobile Belt interface: implication for the Ur supercontinent assembly Geological Journal 47 pp. 312-333.

Manikyamba C, Ray J, Ganguly S, Singh M R, Santosh M, Saha A and Satyanarayanan M (2015) Boninitic metavolcanic rocks and island arc tholeiites from the Older Metamorphic Group (OMG) of Singhbhum Craton, eastern India: Geochemical evidence for Archean subduction processes Precambrian Research 271 138-159

Marchi S, Bottke W F, Elkins-Tanton L T, Bierhaus M, Wuennemann K, Morbidelli A and Kring D A (2014) Wide spread mixing and burial of Earth's Hadean crust by asteroid impacts Nature 511578 
Mazumder R (2006) Large Igneous Provinces, Mantle Plumes and Uplift: A Case Study from the Dhanjori Formation, India. http:// www.MantlePlumes.org.

Mazumder R and Arima M (2009) Implication of mafic magmatism in an intracontinental rift setting: A case study from the Paleoproterozoic Dhanjori formation, Singhbhum crustal province, India The Journal of Geology 117 455466

Mazumder R, Eriksson P G, De S, Bumby A J and Lenhardt N (2012a) Palaeoproterozoic sedimentation on the Singhbhum craton: global context and comparisonwith Kaapvaal. In: Mazumder R and Saha D. (Eds.), Palaeoproterozoic of India Geological Society of London, Special Publications 365 51-76

Mazumder R and Sarkar S (2004) Sedimentation history of the Palaeoproterozoic Dhanjori Formation, Singhbhum, eastern India Precambrian Research 130 267-287

Mazumder R, Van Loon A J, Mallik L, Reddy S M, Arima M, Altermann W, Eriksson P G and De S (2012b) Mesoarchaean-Palaeoproterozoic stratigraphic record of the Singhbhum crustal province, eastern India: A synthesis. In Mazumder R and Saha D (Eds.), Palaeoproterozoic of India Geological Society, London, Special Publications 365 31-49

Miller S R, Mueller P A, Meert J G, Kamenov G D, Pivarunas A F, Sinha A K and Pandit M K (2018) Detrital zircons reveal evidence of Hadean crust in the Singhbhum craton, India The Journal of Geology 126 541-552

Misra S (1999) The Mayurbhanj Granite: Its nature, tectonic setting, mode of emplacement and pressure-temperature of magma generation Indian Journal of Geology 71 33-52

Misra S, Deomurari M, Wiedenbeck M, Goswami J, Ray S and Saha A (1999) 207Pb/206Pb zircon ages and the evolution of the Singhbhum Craton, eastern India: an ion microprobe study Precambrian Research 93 139-151

Misra S and Johnson P T (2005) Geochronological constraints on evolution of Singhbhum mobile belt and associated basic volcanics of eastern Indian shield Gondwana Research $\mathbf{8}$ 129-142

Misra S, Sarkar S S and Ghosh S (2002) Evolution of Mayurbhanj Granite Pluton, eastern Singhbhum, India: a case study of petrogenesis of an A-type granite in bimodal association Journal of Asian Earth Sciences 20 965-989

Mondal S K (2009) Chromite and PGE deposits of Mesoarchaean ultramafic-mafic suites within the greenstone belts of the Singhbhum Craton, India: Implications for mantle heterogeneity and tectonic setting Journal of the Geological Society of India 73 36-51
Mondal S K, Frei R and Ripley E M (2007) Os isotope systematics of Mesoarchean chromitite-PGE deposits in the Singhbhum Craton (India): Implications for the evolution of lithospheric mantle Chemical Geology 244 $391-408$

Mondal S K, Khatun S, Prichard H M, Satyanarayanan M and Kumar G R (2019) Platinum-group element geochemistry of boninite-derived Mesoarchean chromitites and ultramafic-mafic cumulate rocks from the Sukinda Massif (Orissa, India) Ore Geology Reviews 104 722-744

Mondal S K, Ripley E M, Li C and Frei R (2006) The genesis of Archean chromitites from the Nuasahi and Sukinda massifs in the SunghbhumCraton, India Precambrian Research 148 45-66

Mondal S K, Ripley E M, Zhou M F and Frei R (2004) Major, trace and platinum-group elements geochemistry of 3.2 Ga Nuasahi ultramafic-mafic massifs in Archean greenstone belts of the Singhbhum Craton, Eastern India: Implications for Archean mantle. In: J G Shellnutt, M F Zhou and K N Pang (Eds.), 'Recent advances in magmatic ore systems in mafic-ultramafic rocks'. Proceedings IGCP Project 479, Hong KongWorkshop, 114-117

Mondal S K and Zhou M F (2010) Enrichment of PGE through interaction of evolved boninitic magmas with early formed cumulates in a gabbro-breccia zone of the Mesoarchean Nuasahi Massif (eastern India) Mineralium Deposita 45 69-91

Moorbath S and Taylor P N (1988) Early Precambrian crustal evolution in eastern India: the ages of the Singhbhum Granite and included remnants of older gneiss Journal of the Geological Society of India 31 82-84

Moorbath S, Taylor P and Jones N (1986) Dating the oldest terrestrial rocks-fact and fiction Chemical Geology 57 63-86

Moyen J F (2011) The composite Archaean grey gneisses: petrological significance, and evidence for a non-unique tectonic setting for Archaean crustal growth Lithos $\mathbf{1 2 3}$ $21-36$

Mukhopadhyay D (1976) Precambrian stratigraphy of Singhbhum - the problems and a prospect Indian Journal of Earth Sciences 3 208-219

Mukhopadhyay D (2001) The Archaean nucleus of Singhbhum: The present state of knowledge Gondwana Research 4 307-318

Mukhopadhyay D, Bhattacharya T, Chakraborty T and Dey A K (1990) Structural pattern in the Precambrian rocks of Sonua-Lotapahar region, North Singhbhum, eastern India. 
Proceedings of the Indian Academy of Sciences - Earth and Planetary Sciences 99 249-268

Mukhopadhyay J, Beukes N, Armstrong R, Zimmermann U, Ghosh $G$ and Medda R (2008) Dating the oldest greenstone in India: a 3.51-Ga precise U-Pb SHRIMP zircon age for dacitic lava of the southern Iron Ore Group, Singhbhum craton The Journal of Geology 116 449-461

Mukhopadhyay J, Crowley Q G, Ghosh G, Ghosh S, Chakrabarti K, Misra B and Bose S (2013) A Mesoarchean Paleosol from eastern India - the second oldest paleosol on earth Mineralogical Magazine 771802

Mukhopadhyay J, Crowley Q G, Ghosh S, Ghosh G, Chakrabarti K, Misra B, Heron K and Bose S (2014) Oxygenation of the Archean atmosphere: New paleosol constraints from eastern India Geology 42 923-926

Mukhopadhyay J, Ghosh G, Beukes N and Gutzmer J (2007) Precambrian colluvial iron ores in the Singhbhum Craton: implications for origin, age of BIF-hosted high-grade iron ores and stratigraphy of the Iron Ore Group Journal of the Geological Society of India $\mathbf{7 0} 34$

Mukhopadhyay J, Ghosh G, Nandi A K and Chaudhuri A K (2006) Depositional setting of the Kolhan Group: its implications for the development of a Meso to Neoproterozoic deep-water basin on the South Indian craton South African Journal of Geology 109 183-192

Mukhopadhyay J, Ghosh G, Zimmermann U, Guha S and Mukherjee T (2012) A 3.51 Ga bimodal volcanics-BIFultramafic succession from Singhbhum Craton: implications for Palaeoarchaean geodynamic processes from the oldest greenstone succession of the Indian subcontinent Geological Journal 47 284-311

Mukhopadhyay J, Mishra B, Chakrabarti K, De S and Ghosh G (2016) Uraniferous paleoplacers of the Mesoarchean Mahagiri Quartzite, Singhbhum craton, India: Depositional controls, nature and source of $>3.0 \mathrm{Ga}$ detrital uraninites Ore Geology Reviews 72 1290-1306

Murty V N and Acharyya S (1975) Lithostratigraphy of the Precambrian rocks around Koira, Sundergarh district, Orissa Journal of the Geological Society of India 16 55-68

Myers J S (1995) The generation and assembly of an Archean supercontinent: evidence from the Yilgarn Craton, Western Australia. In: Coward M P and Ries A C (Eds.) Early Precambrian Processes Geological Society of London, Special Publication 95 143-154

Naik A (2001) A revision of the stratigraphy of Chandiposh area in eastern part of Sundargarh District, Orissa Indian Journal of Geology 73 119-137
Naqvi S M and Rodgers J J W (1987) Precambrian Geology of India. Oxford University Press, 223p.

Nelson D R, Bhattacharya H N, Thern E R and Altermann W (2014) Geochemical and ion-microprobe U-Pb zircon constraints on the Archaean evolution of Singhbhum Craton, eastern India Precambrian Research 255 412-432

Nutman A P, Friend C R, Horie K and Hidaka H (2007) The Itsaq Gneiss Complex of Southern West Greenland and the Construction of Eoarchaean Crust at Convergent Plate Boundaries. In: Van Kranendonk M J, Smithies R H and Bennett V (Eds.) Earth's Oldest Rocks Developments in Precambrian Geology 15 187-218

Olierook H K H, Clark C, Reddy S M, Mazumder R, Jourdan F and Evans N J (2019) Evolution of the Singhbhum Craton and supracrustal provinces from age, isotopic and chemical constraints Earth-Science Reviews, In press, https://doi.org/ 10.1016/j.earscirev.2019.04.020

O'neil J, Carlson R W, Francis D and Stevenson R K (2008) Neodymium-142 evidence for Hadean mafic crust Science 321 1828-1831

O’Neil J, Carlson R W, Paquette J L and Francis D (2012) Formation age and metamorphic history of the Nuvvuagittuq Greenstone Belt Precambrian Research 220 $23-44$

Pandey O P, Mezger K, Ranjan S, Upadhyay D, Villa I M, Nägler T F and Vollstaedt H (2019) Genesis of the Singhbhum Craton, eastern India; implications for Archean crust-mantle evolution of the Earth Chemical Geology 512 85-106

Polat A, Appel P W and Fryer B J (2011) An overview of the geochemistry of Eoarchean to Mesoarchean ultramafic to mafic volcanic rocks, SW Greenland: Implications for mantle depletion and petrogenetic processes at subduction zones in the early Earth Gondwana Research 20 255-283

Polat A and Frei R (2005) The origin of early Archean banded iron formations and of continental crust, Isua, southern West Greenland Precambrian Research 138 151-175

Polat A, Li J, Fryer B, Kusky T, Gagnon J and Zhang S (2006) Geochemical characteristics of the Neoarchean (2800-2700 Ma) Taishan greenstone belt, North China Craton: evidence for plume-craton interaction Chemical Geology 230 6087

Polat A, Hofmann A and Rosing M T (2002) Boninite-like volcanic rocks in the 3.7-3.8 Ga Isua greenstone belt, West Greenland: geochemical evidence for intra-oceanic subduction zone processes in the early Earth Chemical geology 184 231-254

Polat A, Kerrich R and Wyman D (1998) The late Archean 
Schreiber-Hemlo and White River-Dayohessarah greenstone belts, Superior Province: collages of oceanic plateaus, oceanic arcs, and subduction-accretion complexes Tectonophysics 289 295-326

Polat A, Kokfelt T, Burke K C, Kusky T M, Bradley D C, Dziggel A and Kolb J (2016) Lithological, structural, and geochemical characteristics of the Mesoarchean Târtoq greenstone belt, southern West Greenland, and the Chugach-Prince William accretionary complex, southern Alaska: Evidence for uniformitarian plate-tectonic processes Canadian Journal of Earth Sciences 53 13361371

Prabhakar N and Bhattacharya A (2013) Paleoarchean partial convective overturn in the Singhbhum Craton, Eastern India Precambrian Research 231 106-121

Puchtel I, Hofmann A, Mezger K, Jochum K, Shchipansky A and Samsonov A (1998) Oceanic plateau model for continental crustal growth in the Archaean: a case study from the Kostomuksha greenstone belt, NW Baltic Shield Earth and Planetary Science Letters 155 57-74

Reimink J R, Chacko T, Stern R A and Heaman L M (2014) Earth's earliest evolved crust generated in Iceland-like setting Nature Geoscience 7 529-533

Roy A, Sarkar A, Jayakumar S, Aggarwal S K, Ebihara M and Satoh H (2004) Late Archaean mantle metasomatism below eastern Indian craton: Evidence from trace elements, REE geochemistry and Sr-Nd-O isotope systematics of ultramafic dykes Proceedings of the Indian Academy of Sciences-Earth and Planetary Science 113 649-665

Roy A, Sarkar A, Jeyakumar S and Ebihara M (2002) Sm-Nd age and mantle source characteristics of the Dhanjori volcanic rocks, eastern India Geochemical Journal 36 503-518

Roy A B and Bhattacharya H N (2012) Tectonostratigraphic and geochronologic reappraisal constraining the growth and evolution of Singhbhum Archaean craton, eastern India Journal Geological Society of India 80 455-469

Saha A K (1994) Crustal evolution of Singhbhum-North Orissa, eastern India Journal of the Geological Society of India, Memoir 27341

Saha A, Basu A R, Garzione C N, Bandyopadhyay P K and Chakrabarti A (2004) Geochemical and petrological evidence for subduction-accretion processes in the Archean Eastern Indian Craton Earth and Planetary Science Letters 220 91-106

Saha A K, Ghosh S N, Dasgupta D, Mukhopadhyay K and Ray S L (1984) Studies on crustal evolution of the SinghbhumOrissa Iron-Ore craton. Crustal Evolution and Metallogenesis in Selected Areas of the Indian Shield Indian
Society of Earth Science, Monograph Volume, Calcutta, 174

Saha A K and Ray S L (1984) The structural and geochemical evolution of the Singhbhum granite batholithic complex, India Tectonophysics 105 163-176

Saha A K, Ray S L and Sarkar S N (1988) Early history of the earth: Evidence from the eastern India shield Memoir, Geological Society of India 8 13-38

Saha L, Hofmann A and Xie H (2012) Archaean evolution of the Singhbhum Craton: constraints from new metamorphicgeochemical data and SHRIMP zircon ages. In: Abstract Volume, Conference on Craton Formation and Destruction, University of Johannesburg, 21-22 July 7-9

Santosh M, Arai T and Maruyama S (2017) Hadean Earth and primordial continents: The cradle of prebiotic life Geoscience Frontiers 8 309-327

Sarkar S C and Gupta A(2012) Crustal evolution and metallogeny in India, Cambridge University Press. pp. 840

Sarkar S N and Saha A K (1962) A revision of the Precambrian stratigraphy and tectonics of Singhbhum and adjacent regions Quarternary Journal of Geological Mining and Metallurgica Society of India 34 97-136

Sarkar S N and Saha A K (1977) The present status of the Precambrian stratigraphy, tectonics and geochronology of Singhbhum-Keonjhar-Mayurbhanj region, Eastern India Indian Journal of Earth Sciences, Prof. S Ray Volume, 3765.

Sen T (2001) Stratigraphy and structure of the metamorphic belt at the nothern fringe of Bonai granitic complex in the southeastern part of Sundargarh district, Orissa Geological Survery of India, Special Publication 55 113-128

Sengupta S, Acharyya S and DeSmeth J B (1997) Geochemistry of Archaean volcanic rocks from Iron Ore supergroup, Singhbhum, eastern India Proceedings of the Indian Academy of Sciences-Earth and Planetary Sciences 106 327

Sengupta S, Corfu F, McNutt R and Paul D K (1996) Mesoarchaean crustal history of the eastern Indian craton: $\mathrm{Sm}-\mathrm{Nd}$ and $\mathrm{U}-\mathrm{Pb}$ isotopic evidence Precambrian Research 77 17-22

Sengupta S, Paul D K, De Laeter J, McNaughton N, Bandopadhyay P and DeSmeth J (1991) Mid-Archaean evolution of the eastern Indian craton: geochemical and isotopic evidence from the Bonai pluton Precambrian Research 49 23-37

Shankar R, Vijayagopal B and Kumar A (2014) Precise Pb-Pb baddeleyite ages of $1765 \mathrm{Ma}$ for a Singhbhum 'Newer 
Dolerite' dyke swarm Current Science 106 1306-1310

Sharma M, Basu A R and Ray S L (1994) Sm-Nd isotopic and geochemical study of the Archean tonalite-amphibolite association from the eastern Indian Craton Contributions to Mineralogy and Petrology 117 45-55

Singh M R, Manikyamba C, Ganguly S, Ray J, Santosh M, Singh T D and Kumar B C (2017) Paleoproterozoic arc basaltboninite-high magnesian andesite- $\mathrm{Nb}$ enriched basalt association from the Malangtoli volcanic suite, Singhbhum Craton, eastern India: geochemical record for subduction initiation to arc maturation continuum Journal of Asian Earth Sciences 134 191-206

Singh M R, Manikyamba C, Ray J, Ganguly S, Santosh M, Saha A, Rambabu S and Sawant S (2016) Major, trace and platinum group element (PGE) geochemistry of Archean Iron Ore Group and Proterozoic Malangtoli metavolcanic rocks of Singhbhum Craton, Eastern India: Inferences on mantle melting and sulphur saturation history Ore Geology Reviews 72 1263-1289

Sreenivas B, Dey S, Rao Y B, Kumar T V, Babu E and Williams I $S$ (2019) A new cache of Eoarchaean detrital zircons from the Singhbhum craton, eastern India and constraints on early Earth geodynamics Geoscience Frontiers (In Press), https://doi.org/10.1016/j.gsf.2019.02.001

Srivastava R K, Söderlund U, Ernst R E, Mondal S K and Samal A K (2016) Neoarchaean-Palaeoproterozoic Mafic Dyke Swarms from the Singhbhum Granite Complex, Singhbhum Craton, Eastern India: implications for identification of Large Igneous Provinces and their possible continuation on other formerly adjacent crustal blocks Acta Geologica Sinica (English Edition) 90 17-18

Srivastava R K, Söderlund U, Ernst R E, Mondal S K and Samal AK (2019) Precambrian mafic dyke swarms in the Singhbhum craton (eastern India) and their links with dyke swarms of the eastern Dharwar craton (southern India). Precambriann Research, In press. https://doi.org/10.1016/ j.precamres.2018.08.001

Sunilkumar T, Parthasarathy R, Palrecha M, Shah V, Sinha K and Krishna Rao N (1996) Chemical age of detrital zircons from the basal quartz-pebble conglomerate of Dhanjori Group, Singbhum craton, Eastern India Current Science $71482-486$
Stern R J (2018) The evolution of plate tectonics Philosophical Transaction Royal Society A376 20170406. http://dx.doi. org/10.1098/rsta.2017.0406

Tait J, Zimmermann U, Miyazaki T, Presnyakov S, Chang Q, Mukhopadhyay J and Sergeev S (2011) Possible juvenile Palaeoarchaean TTG magmatism in eastern India and its constraints for the evolution of the Singhbhum craton Geological Magazine 148 340-347

Topno A, Dey S, Liu Y and Zong K (2018) Early Neoarchaean Atype granitic magmatism by crustal reworking in Singhbhum craton: Evidence from Pala Lahara area, Orissa Journal of Earth System Science 127 1-22

Upadhyay D, Chattopadhyay S, Kooijman E, Mezger K and Berndt J (2014) Magmatic and metamorphic history of Paleoarchean tonalite-trondhjemite-granodiorite (TTG) suite from the Singhbhum craton, eastern India Precambrian research 252 180-190

Van Kranendonk M J (2010) Two types of Archean continental crust: Plume and plate tectonics on early Earth American Journal of Science 310 1187-1209

Van Kranendonk M J, Collins W, Hickman A and Pawley M J (2004) Critical tests of vertical vs. horizontal tectonic models for the Archaean East Pilbara granite-greenstone terrane, Pilbara craton, western Australia Precambrian Research 131 173-211

Van Kranendonk M J, Smithies R H, Griffin W L, Huston D L, Hickman A H, Champion D C, Anhaeusser C R and Pirajno F (2015) Making it thick: a volcanic plateau origin of Palaeoarchean continental lithosphere of the Pilbara and Kaapvaal cratons Geological Society of London, Special Publication 389 83-111

Verma R K and Prasad S N (1974) Paleomagnetic study and chemistry of Newer Dolerite from Singhbhum, Bihar, India Canadian Journal of Earth Science 11 1043-1054

Vohra C P, Dasgupta S, Paul D K, Bishui P, Gupta S and Guha S (1991) Rb-Sr chronology and petrochemistry of granitoids from the south-eastern part of the Singhbhum craton, Orissa Journal of the Geological Society of India 38 5-22

Zeh A, Gerdes A, Klemd R and Barton Jr J (2008) U-Pb and Lu$\mathrm{Hf}$ isotope record of detrital zircon grains from the Limpopo Belt-evidence for crustal recycling at the Hadean to early-Archean transition Geochimica Cosmochimica Acta 72 5304-5329. 